\title{
Hizikia fusiformis: Pharmacological and Nutritional Properties
}

\author{
Maria Dyah Nur Meinita ${ }^{1,2,3, * \mathbb{D}}$, Dicky Harwanto ${ }^{1,4}$, Jae-Hak Sohn ${ }^{1,5}$, Jin-Soo Kim ${ }^{6, *}$ and Jae-Suk Choi ${ }^{1,5, *(D)}$ \\ 1 Seafood Research Center, Industry Academy Cooperation Foundation (IACF), Silla University, 606, \\ Advanced Seafood Processing Complex, Wonyang-ro, Amnam-dong, Seo-gu, Busan 49277, Korea; \\ dickyharwanto@lecturer.undip.ac.id (D.H.); jhsohn@silla.ac.kr (J.-H.S.) \\ 2 Faculty of Fisheries and Marine Science, Jenderal Soedirman University, Purwokerto 53123, Indonesia \\ 3 Center for Maritime Bioscience Studies, Jenderal Soedirman University, Purwokerto 53123, Indonesia \\ 4 Faculty of Fisheries and Marine Science, Diponegoro University, Semarang 50275, Indonesia \\ 5 Department of Food Biotechnology, College of Medical and Life Sciences, Silla University, 140, \\ Baegyang-daero 700 beon-gil, Sasang-gu, Busan 46958, Korea \\ 6 Department of Seafood and Aquaculture Science, Gyeongsang National University, 38 Cheongdaegukchi-gil, \\ Tongyeong-si 3064, Korea \\ * Correspondence: maria.meinita@unsoed.ac.id (M.D.N.M.); jinsukim@gnu.ac.kr (J.-S.K.); \\ jsc1008@silla.ac.kr (J.-S.C.); \\ Tel.: +62-281-642-360 (M.D.N.M.); +82-557-729-146 (J.-S.K.); +82-512-487-789 (J.-S.C.)
}

Citation: Meinita, M.D.N.;

Harwanto, D.; Sohn, J.-H.; Kim, J.-S.; Choi, J.-S. Hizikia fusiformis: Pharmacological and Nutritional Properties. Foods 2021, 10, 1660. https://doi.org/10.3390/ foods 10071660

Academic Editors: Ermelinda Prato and Francesca Biandolino

Received: 19 June 2021

Accepted: 15 July 2021

Published: 19 July 2021

Publisher's Note: MDPI stays neutral with regard to jurisdictional claims in published maps and institutional affiliations.

Copyright: (c) 2021 by the authors. Licensee MDPI, Basel, Switzerland. This article is an open access article distributed under the terms and conditions of the Creative Commons Attribution (CC BY) license (https:// creativecommons.org/licenses/by/ $4.0 /)$.
Abstract: The brown seaweed Hizikia fusiformis (syn. Sargassum fusiforme), commonly known as "Hijiki", has been utilized in traditional cuisine and medicine in East Asian countries for several centuries. H. fusiformis has attracted much attention owing to its rich nutritional and pharmacological properties. However, there has been no comprehensive review of the nutritional and pharmacological properties of $H$. fusiformis. The aim of this systematic review was to provide detailed information from the published literature on the nutritional and pharmacological properties of $H$. fusiformis. A comprehensive online search of the literature was conducted by accessing databases, such as PubMed, SpringerLink, ScienceDirect, and Google Scholar, for published studies on the nutritional and pharmacological properties of $H$. fusiformis between 2010 and 2021. A total of 916 articles were screened from all the databases using the preferred reporting items for systematic reviews and meta-analyses method. Screening based on the setdown criteria resulted in 59 articles, which were used for this review. In this review, we found that there has been an increase in the number of publications on the pharmacological and nutritional properties of $H$. fusiformis over the last 10 years. In the last 10 years, studies have focused on the proximate, mineral, polysaccharide, and bioactive compound composition, and pharmacological properties, such as antioxidant, anticancer, antitumor, anti-inflammatory, photoprotective, neuroprotective, antidiabetic, immunomodulatory, osteoprotective, and gastroprotective properties of $H$. fusiformis extracts. Overall, further studies and strategies are required to develop $H$. fusiformis as a promising resource for the nutrition and pharmacological industries.

Keywords: Hizikia fusiformis; Sargassum fusiforme; hijiki; nutritional properties; pharmacological properties

\section{Introduction}

Hizikia fusiformis (Harvey) Okamura, commonly known as "hijiki seaweed" (syn. Sargassum fusiforme (Harvey) Setchell), is an edible brown alga belonging to the class Phaeophyceae, order Fucales, and family Sargassaceae. H. fusiformis grows naturally on lower intertidal rocks around the coastline of the northwest Pacific Ocean [1], and is widely used as a food delicacy, marine vegetable, and medicinal herb in China, Korea, Japan, and Southeast Asia [2]. Currently, H. fusiformis has been effectively cultivated in southern China and Korea. In 2015, South Korea produced 28,157 tons of H. fusiformis dry weight (DW) ha ${ }^{-1}$ year $^{-1}$ with a value of USD 15,227,000, making South Korea one of the largest producers of Hizikia worldwide [3]. 
The demand for $H$. fusiformis has increased owing to its nutritional potential as well as to its economic value in the pharmaceutical and manufacturing industries [4]. Most of the existing studies on $H$. fusiformis have mainly focused on the industrial use of its hydrocolloid; however, recent studies have examined the medical efficacy of $H$. fusiformis. Several compounds such as polysaccharides, fucoidan, fucosterol, and phenols with various pharmacological properties have been isolated and identified from H. fusiformis [4-7]. These bioactive compounds show anti-inflammatory [8], antioxidant [9], antitumor [10], immunomodulatory [11], and protective effects against osteo-disease [12,13]. Among the various bioactive compounds found in seaweed, phenolic compounds have attracted the most interest. Some comprehensive studies have investigated phenolic compounds of terrestrial plants, including their antioxidant properties $[14,15]$. Humans need antioxidants to prevent the formation of free radicals and reactive oxygen species (ROS), which can cause lipid peroxidation and cell damage. Seaweed, as a benthic marine organism that can survive in harsh and exposed environments, produces high concentrations of phenolic compounds in the form of phlorotannin as an antioxidant source. The phlorotannin and phenolic compounds in seaweed can potentially be used in reducing oxidative reactions in biological systems [16-18]. For instance, the hydrophilic phlorotannins extracted from $H$. fusiformis showed significantly higher radical scavenging activities than did those from original extracts and can be developed as a great source of natural antioxidative nutraceuticals [19]. However, compared with those from terrestrial plants, phenolic compounds from seaweed have not been studied extensively, and no comprehensive review papers regarding the pharmacology and nutritional properties of $H$. fusiformis have been published. Therefore, the aim of this systematic review was to provide detailed information from the published literature on the nutritional and pharmacological properties of $H$. fusiformis.

\section{Materials and Methods}

We conducted a systematic literature review of the published studies on the pharmacological properties of $H$. fusiformis. The literature was analyzed using the Preferred Reporting Items for Systematic reviews and Meta-Analyses (PRISMA) method [20] (Figure 1).

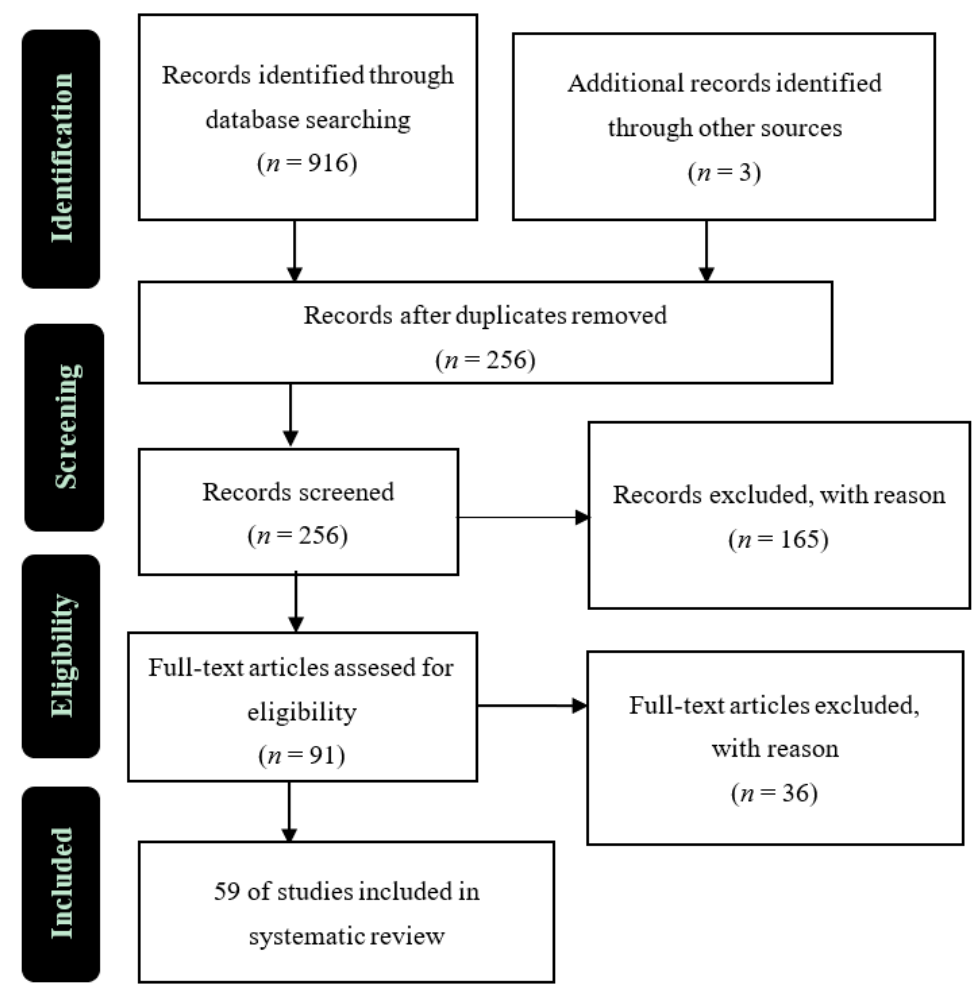

Figure 1. Summarized search method based on the PRISMA method. 
A comprehensive online search of the literature was conducted by accessing the following databases: PubMed, SpringerLink, ScienceDirect, and Google Scholar, for studies published between 2010 and 2021. We used the keyword "Hizikia fusiformis", "Sargassum fussiforme", and "hijiki" combinations in the title, abstract, or text content. The complete list of identified articles was maintained using Mendeley's open-source reference management (https:/ / www.mendeley.com/ (accessed on 1 March to 18 July 2021)).

Articles obtained from the database search using the search criteria above were aggregated in the second stage, and duplicate articles were removed. Furthermore, article screening was conducted by reading the 'title' and then the 'abstract'. Studies that did not meet the inclusion criteria were excluded. In the final stage, the remaining articles were screened by reading the full text, and articles that did not meet the inclusion criteria were excluded. The remaining articles were analyzed and extracted, and data were presented in tables and graphs.

\section{Results}

A total of 916 articles were screened from all the databases using the PRISMA method. Three more publications were discovered by manually scanning the reference lists. After the selection process, a total of 59 articles were analyzed and are summarized in Figure 2. Among the 59 articles included in the study, seven examined the nutritional properties (proximate composition, major mineral, trace element, and polysaccharide) of H. fusiformis, 29 examined its pharmacological properties, and 24 examined both topics. Studies on the pharmacological and nutritional properties of H. fusiformis between 2010 and 2021 are summarized in Figure 2.

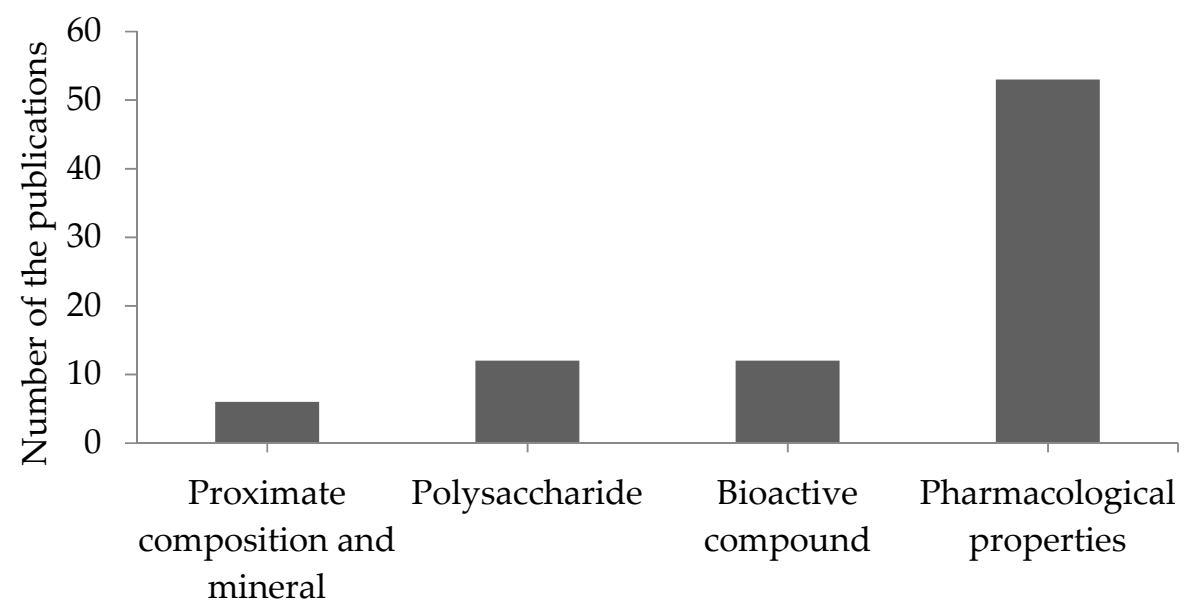

Figure 2. The number of publications related to the nutritional and pharmacological properties of H. fusiformis.

Between 2010 and 2021, published articles on the pharmacological properties of $H$. fusiformis focused on the antibacterial $(3.77 \%)$, antioxidant $(15.09 \%)$, anticancer and antitumor $(15.09 \%)$, anti-inflammatory $(11.32 \%)$, photoprotective $(11.32 \%)$, neuroprotective $(11.32 \%)$, antidiabetic $(9.43 \%)$, immunomodulatory $(9.43 \%)$, osteoprotective $(7.55 \%)$, and gastroprotective (5.66\%) properties of H. fusiformis (Figure 3 ).

\subsection{Nutritional Properties}

Seaweed is a leading material in the production of new medicines, food formulations, and cosmetics because it contains several important macronutrients such as proteins, carbohydrates, and minerals. Additionally, seaweed is a rich source of health-promoting secondary metabolites, such as phenols, flavonoids, alkaloids, and tannins, with a wide range of applications in the treatment of several disorders and diseases. 


\subsubsection{Proximate Composition}

The proximate composition of $H$. fusiformis, including total carbohydrates, crude protein, crude lipid, crude fiber, ash content, and moisture content, is presented in Table 1.

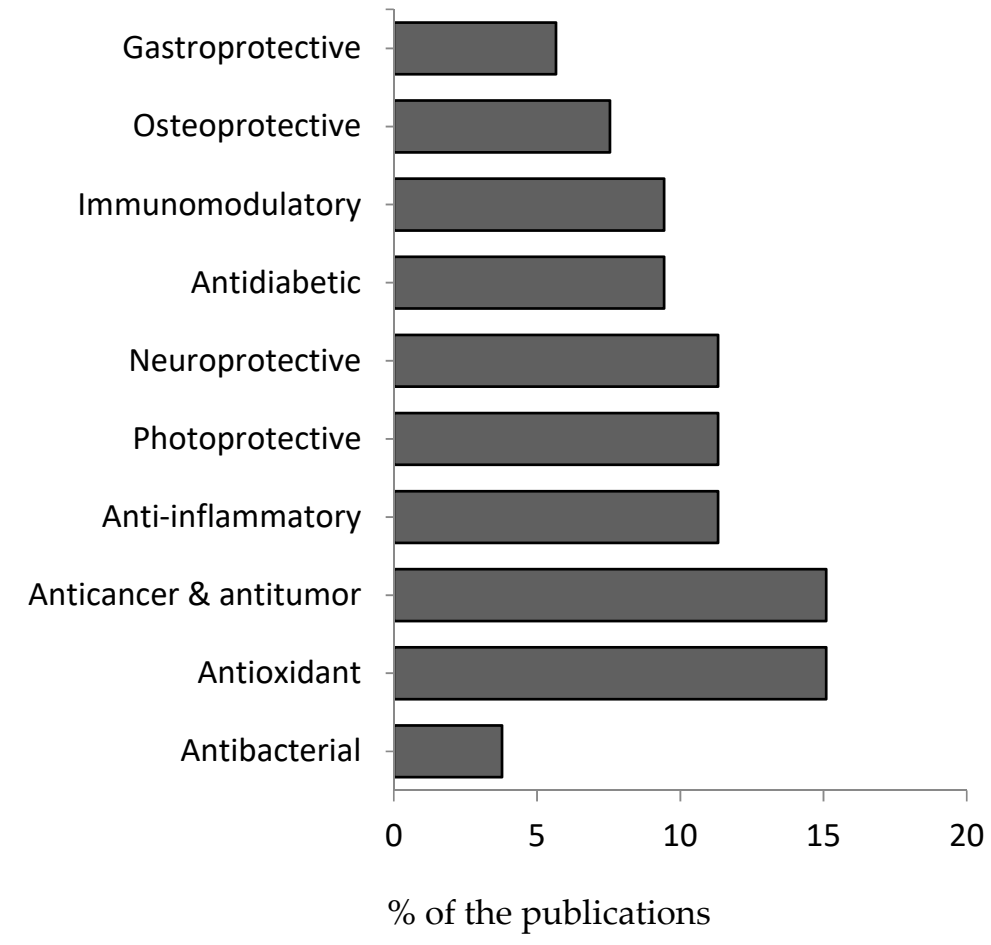

Figure 3. Current research trends of the pharmacological properties of $H$. fusiformis.

Table 1. Proximate composition of $H$. fusiformis.

\begin{tabular}{|c|c|c|c|c|c|c|}
\hline \multicolumn{6}{|c|}{ Primary Metabolite (\% DW) } & \multirow{2}{*}{ Reference } \\
\hline Carbohydrates & Protein & Lipid & Fiber & Ash Content & Moisture & \\
\hline 40.73 & 18.41 & nd & nd & 16.63 & nd & [21] \\
\hline nd & 12.2 & 1.8 & 11.3 & 14 & nd & [22] \\
\hline $61.85 \pm 3.56$ & $12.94 \pm 3.61$ & $1.76 \pm 0.07$ & nd & $19.18 \pm 0.09$ & $4.27 \pm 0.12$ & {$[23,24]$} \\
\hline nd & $10.40 \pm 0.59$ & $1.38 \pm 0.08$ & nd & $17.89 \pm 0.05$ & $5.71 \pm 0.34$ & [25] \\
\hline nd & 9.9 & 1.2 & nd & 40 & 9.5 & [26] \\
\hline
\end{tabular}

$\% \mathrm{DW}, \mathrm{g} / 100 \mathrm{~g}$ on a dry weight basis; nd, not determined.

The primary metabolites of $H$. fusiformis are essential for its survival, growth, and proliferation. In terms of nutrition, $H$. fusiformis has been used as a food due to its high nutrient value and low calorific content. The carbohydrate content is high (average of 50\% of its dry weight); however, a large percentage is in the form of dietary fibers, which are undigestible by humans. Moreover, dietary fibers are beneficial to human health because of their positive effects on the intestinal environment $[27,28]$. The total carbohydrate content of $H$. fusiformis ranged from $40.73-61.85 \%$ DW $[21,23,24]$, which is similar to the carbohydrate content of brown seaweeds $(12.2-56.4 \%$ DW) reported in previous studies [27,29].

The protein content of $H$. fusiformis ranged from 9.9-18.41\% DW. Brown seaweeds, especially the genus Sargassum, have low protein contents (9-20\% DW) compared to other seaweed groups [28] and terrestrial vegetable protein sources, such as soybean (40\% DW) [30]. Despite their low protein content, seaweeds may be considered potential sources of protein for human and animal nutrition because protein is the building block of living tissues and organs, making it essential in human and animal diets [29].

The lipid content of $H$. fusiformis ranged from $1.2-1.76 \%$ DW. Seaweeds are generally low in lipids $(0.1-4.5 \%$ DW) [31,32]. Although the lipid content of seaweed is low, it is important to differentiate them based on their chemical characteristics [29]. Polyunsaturated 
fatty acids (PUFAs), derived from algae, have been shown to play important roles as an energy source and in cell-membrane components [31].

The fiber content of $H$. fusiformis reported in this review $(11.3 \% \mathrm{DW})$ was higher than that of Laminaria japonica, Porphyra tenera, Undaria pinnatifida, and Palmaria palmata (6.5-8.0\% DW). Thus, confirming the results of previous studies that reported higher fiber content for brown seaweed compared with that of red and green seaweed [29]. Generally, the daily dietary fiber level of human diet is low [33], making H. fusiformis an alternative and sustainable dietary fiber source $[34,35]$. Although some seaweed-derived fibers (alginate, carrageenan, and agar) have been used for years to enhance the sensory properties of food because of their emulsifying, thickening, and stabilizing properties, there has been little interest in their use as functional dietary fibers [36].

According to the findings of this review, H. fusiformis contains high amounts of ash (14-40\% DW). Previous studies have reported that brown seaweed contains a higher ash content (19.60-45.48\%) DW than red and green seaweed and most terrestrial plants [37,38]. A high ash content may indicate the presence of significant amounts of various mineral components [39]. Furthermore, the ash content of seaweeds is dependent on geographical, environmental, and physiological factors [40].

The moisture content of $H$. fusiformis reported in the reviewed studies exhibited a narrow range of variation, from 4.0-9.5\% DW. Moisture content is an important parameter in evaluating the quality and shelf life of processed seaweed because high moisture can accelerate microbial activity and spoilage [41]. The amount of water in food or animal feed affects its usability and quality, such as texture, taste, appearance, and stability. Therefore, moisture content is critical in the utilization of seaweeds in several industries, including the food, chemical, and pharmaceutical industries [42].

\subsubsection{Major Minerals and Trace Elements}

Seaweeds contain higher amounts of major minerals (macrominerals) and trace elements (microminerals) than terrestrial edible plants, making them a sustainable mineral source in human nutrition [37]. Edible seaweeds provide all of the essential nutrients, including calcium $(\mathrm{Ca})$, magnesium $(\mathrm{Mg})$, potassium $(\mathrm{K})$, sodium $(\mathrm{Na})$, phosphate $(\mathrm{P})$, iron $(\mathrm{Fe})$, copper $(\mathrm{Cu})$, manganese $(\mathrm{Mn})$, and zinc $(\mathrm{Zn})$. Major minerals are constituents of vital cellular components, such as proteins and nucleic acids. Trace elements are defined as chemical elements contained in natural materials that are needed by humans in small amounts $(<100 \mu \mathrm{g} / \mathrm{g})$. Both major minerals and trace elements play important roles in biochemical reactions in living organisms in minute quantities [43]. The mineral profile of H. fusiformis is shown in Table 2.

Table 2. Mineral profile of $H$. fusiformis.

\begin{tabular}{cc}
\hline Metabolite Class & Dietary Content (\%DW) \\
\hline Major minerals & $0.87-1.17$ \\
$\mathrm{Ca}$ & $0.01-0.63$ \\
$\mathrm{Mg}$ & $0.32-1.14$ \\
$\mathrm{~K}$ & $0.16-0.83$ \\
$\mathrm{Na}$ & 0.11 \\
$\mathrm{P}$ & $14.3-47.6$ \\
Trace elements & 0.7 \\
$\mathrm{Fe}$ & 1.7 \\
$\mathrm{Cu}$ & $1.5-1.6$ \\
$\mathrm{Mn}$ & \\
$\mathrm{Zn}$ & \\
\hline \% DW, g/100 g on a dry weight basis. Adapted from Choi et al., (2014) and Zheng et al., (2013) [21,22].
\end{tabular}

$\%$ DW, g/100 g on a dry weight basis. Adapted from Choi et al., (2014) and Zheng et al., (2013) [21,22].

As shown in Table 2, Ca was the most abundant major mineral $(0.87-1.17 \%$ DW) in H. fusiformis, followed by $\mathrm{Mg}(0.01-0.63 \% \mathrm{DW}), \mathrm{K}(0.32-1.14 \% \mathrm{DW}), \mathrm{Na}(0.16-0.83 \%$ $\mathrm{DW})$, and $\mathrm{P}(0.01 \% \mathrm{DW})[21,22]$. Overall, the values reported here are in accordance with previous findings for brown seaweed $[27,44]$. The calcium content of $H$. fusiformis was higher than that of terrestrial foods, such as whole milk (115 mg/100 g), brown 
rice $(110 \mathrm{mg} / 100 \mathrm{~g})$, peanuts $(60.0 \mathrm{mg} / 100 \mathrm{~g})$, and bananas $(6 \mathrm{mg} / 100 \mathrm{~g})$ [45]. Among the trace elements examined in this review, Fe (14.3-47.6\% DW) was the most abundant microelement, followed by $\mathrm{Cu}(0.7 \% \mathrm{DW}), \mathrm{Mn}(1.7 \% \mathrm{DW})$, and $\mathrm{Zn}(1.5-1.6 \% \mathrm{DW})[21,22]$. The values reported here were consistent with those of previous studies on brown seaweed mineral content [27].

\subsubsection{Polysaccharide}

As previously mentioned, brown seaweeds contain high levels of polysaccharides, such as fucoidan, alginate, and laminaran. Polysaccharides extracted from $\mathrm{H}$. fusiformis were characterized based on their molecular weight, sulfate content, uronic acid, total carbohydrates, and neutral sugar components (Table 3).

Table 3. The polysaccharide profile of $H$. fusiformis.

\begin{tabular}{|c|c|c|c|c|c|c|c|}
\hline \multirow{2}{*}{$\begin{array}{c}\text { Type of } \\
\text { Polysaccharides }\end{array}$} & \multirow{2}{*}{ Mw (kDa) } & \multicolumn{4}{|c|}{$\begin{array}{c}\text { Chemical Composition } \\
\text { (\%DW) }\end{array}$} & \multirow{2}{*}{$\begin{array}{l}\text { Monosaccharide } \\
\text { Composition } \\
\text { (Weight Ratio) }\end{array}$} & \multirow{2}{*}{ Ref. } \\
\hline & & $\begin{array}{c}\text { Total } \\
\text { Carbohydrate }\end{array}$ & Sulfate & Uronic Acid & Protein & & \\
\hline Fucoidan & 102.67 & $71.79 \pm 0.56$ & $27.22 \pm 0.05$ & nd & nd & $\begin{array}{l}\text { Fuc:Rha:Glc:Man:Ara } \\
=79.2: 2 \cdot 1: 0.2: 18 \cdot 1: 0.4\end{array}$ & {$[46]$} \\
\hline $\begin{array}{c}\text { Crude } \\
\text { polysaccharide }\end{array}$ & 75 & 97.9 & 9.2 & 51.2 & nd & $\begin{array}{l}\text { Fuc:Rha:Glc:Man:Xyl: } \\
\text { Gal:GluA:ManA:GulA } \\
=\text { 28.9:5.3:1:6.1:5.2:9.1: } \\
\text { 3.8:8.8:38.9 }\end{array}$ & [9] \\
\hline Fucoidan & 90 & 67.5 & 17.5 & 41.04 & 5.22 & $\begin{array}{c}\text { Fuc:Man:Xyl:Gal: } \\
\text { Glc:GlcA = 19.2:2.6: } \\
\text { 6.6:9.6:1.0:6.5 }\end{array}$ & {$[47]$} \\
\hline $\begin{array}{c}\text { Crude } \\
\text { polysaccharide }\end{array}$ & 229 & 42.69 & 25.69 & nd & nd & Fuc $=19.5$ & {$[48]$} \\
\hline $\begin{array}{c}\text { Crude } \\
\text { polysaccharide }\end{array}$ & 58.28 and 7.46 & $73.86 \pm 0.85$ & $5.17 \pm 0.57$ & $32.62 \pm 1.43$ & $0.51 \pm 0.08$ & $\begin{array}{c}\text { Fuc:Rha:Glc:Man: } \\
\text { Gal:GlcA = 43.9:2.5: } \\
\text { 6.5:16.3:18.7:12.1 }\end{array}$ & [49] \\
\hline Fucoidan & $30-50$ & nd & 11.60 & nd & nd & $\begin{array}{c}\text { Fuc:Rha:Glc:Man:Ara: } \\
\text { Xyl:Gal = 61.5:1.2: } \\
0.7: 5: 0.1: 7.1: 24.5\end{array}$ & [13] \\
\hline $\begin{array}{c}\text { Crude } \\
\text { polysaccharide }\end{array}$ & nd & nd & $63.56 \pm 0.32$ & nd & nd & $\begin{array}{c}\text { Fuc:Glc:Man: } \\
\text { Xyl:Gal = 53.5:5.9: } \\
17.4: 23.1\end{array}$ & {$[50]$} \\
\hline $\begin{array}{c}\text { Crude } \\
\text { polysaccharide }\end{array}$ & 24 & 62.9 & 27.7 & 14.7 & 0.4 & $\begin{array}{c}\text { Fuc:Man:Xyl: } \\
\text { Gal:GalA = 80.6:2.4: } \\
\text { 3.0:13.3:0.7 }\end{array}$ & {$[51]$} \\
\hline $\begin{array}{c}\text { Crude } \\
\text { polysaccharide }\end{array}$ & 299 & nd & 10.74 & 6.48 & nd & $\begin{array}{c}\text { Fuc:Man: } \\
\text { Xyl:Gal = 5.9:2.3: } \\
1.0: 2.2\end{array}$ & {$[52]$} \\
\hline Fucoidan & 47.5 & 16.8 & 20.8 & 34.6 & $\mathrm{Nd}$ & $\begin{array}{c}\text { Fuc:Man:Xyl: } \\
\text { Gal:GlcA = 36.6:7.0: } \\
\text { 18.3:19.1:19.1 }\end{array}$ & {$[53]$} \\
\hline $\begin{array}{c}\text { Crude } \\
\text { polysaccharide }\end{array}$ & 224 & $58.10 \pm 2.12$ & $9.85 \pm 0.96$ & $17.66 \pm 0.54$ & $1.01 \pm 0.15$ & $\begin{array}{c}\text { Fuc:Rha:Glc:Man:Xyl: } \\
\text { Gal:Fru = 28.8:2.3: } \\
\text { 1.0:6.0:3.9:12.3:12.3 }\end{array}$ & {$[54]$} \\
\hline Fucoidan & 205.8 & 68.33 & 14.55 & nd & 4.13 & $\begin{array}{c}\text { Fuc:Rha:Glc:Man: } \\
\text { Xyl:Gal = 16.7:1.0: } \\
\text { 1.6:1.3:1.1:6.2 }\end{array}$ & [55] \\
\hline
\end{tabular}

$\% \mathrm{DW}, \mathrm{mg} / 100 \mathrm{~g}$ on a dry weight basis; $\mathrm{nd}$, not determined; Mw, molecular weight.

Polysaccharides are polymers of simple sugars (monosaccharides) composed of repeating units linked together by glycosidic bonds [56]. Polysaccharides account for $40-50 \%$ of the dry matter of seaweed cell walls [57]. However, it should be noted that the biosynthesis of polysaccharides in seaweeds is influenced by both environmental and ecological 
conditions. Different possibilities exist for monosaccharides linked by glycosidic bonds ( $\alpha$ or $\beta, 1 \rightarrow 3,1 \rightarrow 4,1 \rightarrow$ ) [27]. The monosaccharide sequences present in H. fusiformis were neutral (Fuc, Rha, Glc, Man, Ara, Xyl, Gal, Fru) and acidic (Fuc, Rha, Glc, Man, Ara, Xyl, Gal, Fru) (GlcA, ManA, GalA, GulA), which was consistent with previous reports that monosaccharide sequences can be neutral, acidic, or hexosamines [58,59]. Additionally, it has been reported that these polymers can be both linear (alginate, and cellulose) and branched (fucoidans, and sulfated galactans) [60].

Among polysaccharides, fucoidans have been extensively studied because of their biological activities, including antioxidant, anticoagulant, antithrombotic, antiproliferative, antitumor, anticancer, immunomodulatory, anti-inflammatory, antibacterial, and antidiabetic activities [61,62]. Fucoidans are a type of sulfated polysaccharide with extremely variable molecular weights, and are commonly found in brown seaweed extracts [63]. According to previous studies, the molecular weight of fucoidan in $H$. fusiformis is between 24 and $299 \mathrm{kDa}[9,49,51,52]$. The basic chemical structure of fucoidan is shown in Figure 4.

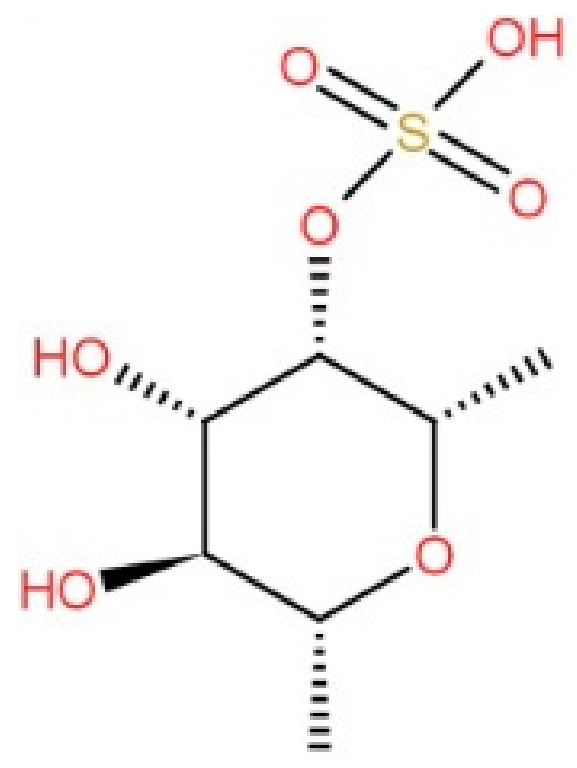

Figure 4. Basic chemical structure of fucoidan.

Fucoidans are typically divided into two types: the first (I) is made up of repeating (13)-L-fucopyranose units, whereas the second (II) alternates repeating (13) and (14)-Lfucopyranose units, which in either case may be substituted with sulfate or acetate and/or have side branches containing fucopyranoses or other glycosyl units, such as glucuronic acid [64]. Fucose is the most abundant monomer of $H$. fusiformis fucoidan, but it also contains galactose, mannose, xylose, and glucuronic acid residues $[46,47,53]$. These components could be contaminated by other polysaccharides or genuine substitutions on fucoidan molecular entities [64]. Nonetheless, seaweed contains a number of polysaccharides that have been studied in numerous scientific articles but are yet to be commercialized.

\subsubsection{Bioactive Compounds}

The recent surge of interest in seaweed has been fueled by its bioactive compounds, which have potential applications in nutraceuticals and pharmaceuticals. Candidate bioactive compounds in $H$. fusiformis that can be developed for industrial applications include polysaccharides (e.g., alginate and fucoidan), polyphenols (e.g., phlorotannins), glycyrrhizin, arsenic, sterol (fucosterol, saringosterol), pigments (e.g., carotenoid fucoxanthin), and fatty acids (e.g., tetradecanoic acid, 9-hexadecenoic acid, palmitic acid, and arachidonic acid) (Table 4). 
Table 4. Bioactive compounds in H. fusiformis.

\begin{tabular}{|c|c|c|}
\hline Chemical & Characteristics & Reference \\
\hline Glycyrrhizin & Its metabolites, $18 \alpha$-glycyrrhetinic acid and $18 \beta$-glycyrrhetinic acid & [65] \\
\hline \multirow{2}{*}{ Phlorotannins } & Total content $88.48 \pm 0.30(\mathrm{mg} / 100 \mathrm{mg}$ DW) & [4] \\
\hline & Total content $43.3 \mu \mathrm{g} / \mathrm{mL}$ & [66] \\
\hline \multirow[t]{2}{*}{ Arsenic compounds } & $\begin{array}{l}\text { Inorganic arsenic: arsenite }[\mathrm{As}(\mathrm{III})] \text { and arsenate }[\mathrm{As}(\mathrm{V})] \text {, and organic arsenic: } \\
\text { dimethylarsinic acid (DMA), monomethylarsonic acid (MMA), arsenobetaine } \\
\text { (AsB), and arsenocholine (AsC) }\end{array}$ & [67] \\
\hline & $\begin{array}{l}\text { H. fusiformis has the highest total As content compared with that of } L \text {. japonica, } P \text {. } \\
\text { yezoensis, U. pinnatifida, E. prolifera. Contains dimethylarsinate (DMA), arsenite [As } \\
\text { (III)], arsenate [As (V)] }\end{array}$ & [68] \\
\hline H. fusiformis functional oil (HFFO) & $\begin{array}{l}\text { Its main components are tetradecanoic acid }(11 \%) \text {, 9-hexadecenoic acid }(2.67 \%) \text {, } \\
\text { palmitic acid }(37.80 \%) \text {, phytol }(33.21 \%) \text {, and arachidonic acid }(15.32 \%)\end{array}$ & [69] \\
\hline \multirow[t]{2}{*}{ Fucosterol } & $\begin{array}{l}\text { The total concentration in normal HF extract }(\mathrm{NH}) \text { and modified HF extract }(\mathrm{EH}) \\
\text { are } 0.249 \mathrm{mg} / \mathrm{g} \text { and } 1.067 \mathrm{mg} / \mathrm{g} \text {, respectively }\end{array}$ & [70] \\
\hline & Non-polar components which are extracted from methanol & [71] \\
\hline \multirow[t]{2}{*}{ Saringosterol } & $\begin{array}{l}\text { 24R-saringosterol is an uncommon sterol in algae, with potential role in the } \\
\text { inhibition of MG63 cell proliferation }\end{array}$ & [6] \\
\hline & Non-polar components which are extracted from methanol & [71] \\
\hline \multirow[t]{2}{*}{ Fucoxanthin } & $\begin{array}{l}\text { Comprised of five pigments: Fx, chlorophyll-a, } \beta \text {-carotene, cis-fucoxanthin, and } \\
\text { pheophytin-a. }\end{array}$ & [8] \\
\hline & Non-polar components which are extracted from methanol & [71] \\
\hline Alginate & $\begin{array}{l}\text { Rich in M blocks and the average molecular weights of 04S2P-S and commercial } \\
\text { alginate (Alg-S) were } 55.5 \mathrm{kDa} \text { and } 557 \mathrm{kDa} \text {, respectively. Sulfation modification in } \\
\text { Alg-S produced higher molecular weights }\end{array}$ & [10] \\
\hline Lectin (HFL) & $\begin{array}{l}\text { Molecular weights ( } 16.1 \mathrm{kDa}) \text { and the monosaccharide units of HFL are glucose, } \\
\text { galactose and fucose. HFL may be linked by N-glucosidic bonds }\end{array}$ & [72] \\
\hline
\end{tabular}

Marine plants can accumulate arsenic from water; hence, seaweeds have higher arsenic contents than terrestrial plants. Zhao et al., (2014) investigated the total arsenic, dimethylarsinate (DMA), arsenite (As (III)), and arsenate (As (V)) contents of seaweeds and found that the total arsenic content of $H$. fusiformis was significantly higher than that of L. japonica, P. yezoensis, U. pinnatifida, and E. prolifera [68]. According to Park et al. [67], H. fusiformis contains inorganic arsenic: arsenite (As (III)) and arsenate (As (V)) and organic arsenic: dimethylarsinic acid (DMA), monomethylarsonic acid (MMA), arsenobetaine (AsB), and arsenocholine (AsC). The chemical structures of the arsenic compounds in H. fusiformis are shown in Figure 5. Generally, inorganic arsenic is more toxic than organic arsenic, and arsenite (As(III)) toxicity is 60 times higher than that of arsenate $(\mathrm{As}(\mathrm{V}))$ [73]. The $\mathrm{LD}_{50}$ values for arsenite, arsenate, MMA, DMA, AsC, and AsB, according to the United States Environmental Protection Agency (EPA), are 15-42, 20-200, 700-1800, 1200-2600, 6500 , and $10,000 \mathrm{mg} / \mathrm{kg}$, respectively [74]. $\mathrm{LD}_{50}$ is a statistically derived concentration that is expected to cause death in $50 \%$ of animals within a particular period of time [75]. Boiling $H$. fusiformis at $90{ }^{\circ} \mathrm{C}$ and soaking in $2 \% \mathrm{NaCl}$ solution reduced the inorganic arsenic intake by consumers [67]. Furthermore, temperature was found to be a significant factor in the removal of inorganic arsenic from $H$. fusiformis using an aqueous extraction method. The optimal removal conditions for inorganic arsenic were a $\mathrm{pH}$ of 4 , a temperature of $50{ }^{\circ} \mathrm{C}$, a removal time of $\geq 8 \mathrm{~h}$, a solid (dry)/liquid ratio of 1:40 ( $\mathrm{m} / \mathrm{v})$, and twice extraction [22].

Yang et al. [69] discovered that the main components of the lipid-soluble subfraction of the $H$. fusiformis functional oil (HFFO) were tetradecanoic acid (11\%), palmitic acid $(37.80 \%)$, 9-hexadecenoic acid $(2.67 \%)$, phytol $(33.21 \%)$, and arachidonic acid $(15.32 \%)$ (Figure 6). These components have anti-neuroinflammatory properties that can help prevent Alzheimer's disease [69]. Generally, oil extracts from terrestrial plants have been shown to possess several biological properties, including anti-inflammatory, neuroprotective, and antioxidant properties, as well as the ability to increase the bioavailability of other 
drugs [76]. However, studies on the essential and functional oils in macroalgae are limited and may represent a source of pharmacologically active compounds.

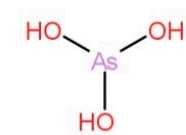

(1) Arsenite (As(III))<smiles>C[As](C)(=O)O</smiles>

(4) Dimethylarsinic acid (DMA(V))

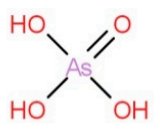

(2) Arsenate $(\mathrm{As}(\mathrm{V}))$

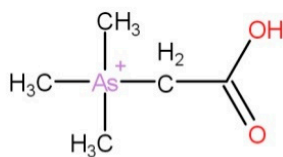

(5) Arsenobetain (AsB)<smiles>CS(=O)(=O)O</smiles>

(3) Monomethylarsonic acid (MMA(V))<smiles>C[Sn](C)(C)CCO</smiles>

(6) Arsenocholine (AsC)

Figure 5. Chemical structures of arsenic compounds found in H. fusiformis. (1) Arsenite (As(III)); (2) arsenate (As(V)); (3) monomethylarsonic acid (MMA(V)); (4) dimethylarsinic acid (DMA(V)); (5) arsenobetaine (AsB); (6) arsenocholine (AsC).

Wagle et al. [65] investigated the activities of glycyrrhizin isolated from $H$. fusiformis, including its metabolites, $18 \alpha$ - and 18 $\beta$-glycyrrhetinic acid, in Alzheimer's disease prevention. Glycyrrhizin, commonly known as glycyrrhizic acid (GLR) or licorice, is a saponin molecule made up of glycyrrhetic acid, a triterpenoid aglycone, and glucuronic acid disaccharide. GLR is frequently extracted using an ethanol solution at high temperatures [77]. GLR has been permitted for use as a food additive in the United States since 1985 and is generally recognized as safe (GRAS). GLR and GLR-containing extracts from three plants, Glycyrrhiza glabra, Glycyrrhiza uralensis Fisch., and Glycyrrhiza inflata Bat., have previously been studied for their characteristics and applications. Furthermore, GLR has been extensively explored in biology and medicine because of its wide range of pharmacological properties, including anti-inflammatory, antioxidant, anti-allergenic, antibacterial, antiviral, antiparasitic, and anticancer activities [78-80]. Based on these results, there is a need for studies to examine the pharmacological properties of GLR present in seaweeds.

Phlorotannins are polyphenols found in brown seaweeds, formed from the oligomerization and decoupling of phloroglucinol (1,3,5-trihydroxybenzene) units, and biosynthesized via the acetate-malonate pathway, commonly known as the polyketide process. Their molecular weight is between $126 \mathrm{kDa}$ and $650 \mathrm{kDa}$, and their content in dried brown seaweeds ranges from $0.5-2.5 \%$ [16,81,82]. According to Li et al. [78] and Liu et al. [4], H. fusiformis contains $88.48 \pm 0.30 \mathrm{mg}$ phloroglucinol equivalents (PGE)/100 $\mathrm{mg}$ of the phlorotannin extract. A total of 42 chemicals with different molecular weights were discovered and tentatively characterized in H. fusiformis, among which, fuhalol-type phlorotannins were the most abundant [83]. The relative abundance of phlorotannins in H. fusiformis and its biological activity has stimulated considerable research into their potential use in several therapeutics.

Additionally, H. fusiformis contains fucosterol, a phytosterol with a non-polar component isolated from methanol extracts [71]. The total fucosterol concentrations in normal $H$. fusiformis extract (NH) and modified $H$. fusiformis extract (EH) were 0.249 and $1.067 \mathrm{mg} / \mathrm{g}$, respectively [70]. Furthermore, fucosterol is an additional liver $\mathrm{X}$ receptor (LXR) agonist that may also play a role in the gene expression profile resulting from $H$. fusiforme supplementation [84]. Liver $X$ receptors (LXRs), LXR $\alpha$ (NR1H3), and LXR $\beta$ (NR1H2) are nuclear receptors that control the metabolism of a variety of essential lipids, such as cholesterol and bile acids [85]. Therefore, further research on the biological activity of $H$. fusiformis is necessary.

Saringosterol is a non-polar sterol found in algae and is derived from methanol [6,71]. Studies have examined the chemical structures of $H$. fusiformis sterols, 24S-saringosterol and 24R-saringosterol $[6,86]$. 24S-saringosterol was more effective than 24R-saringosterol in LXR-mediated transactivation. 24S-saringosterol is a naturally occurring cholesterollowering substance that acts as a selective LXR agonist $[9,86]$. 
<smiles>Oc1cc(O)cc(O)c1</smiles>

(1) Phlorotannin<smiles>CCCCC(C)O[C@H]1OC(C(=O)O)[C@@H](O)[C@H](O)[C@@H]1O[C@@H]1OC(C(=O)O)[C@H](O)[C@H](O)[C@H]1O</smiles>

(8) Fucoxanthin

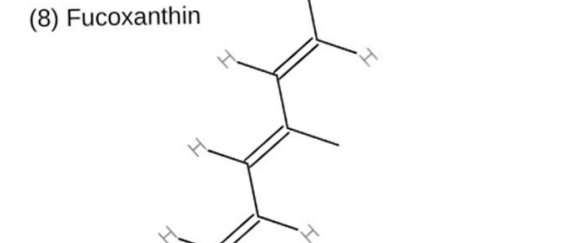<smiles>CCCCCCCCCCCCCC(=O)O</smiles>

(3) Tetradecanoic acid<smiles>CCCCCCC=CCCCCCCCC(=O)O</smiles>

(4) 9-hexadecenoic acid<smiles>CCCCCCCCCCCCCCCC(=O)O</smiles>

(5) Palmitic acid<smiles>C/C(=C\CO)CCC[C@H](C)CCC[C@H](C)CCCC(C)C</smiles>

(6) Phytol<smiles>CCCCCCC=CCC=CCC=CCC=CCCCC(=O)O</smiles>

(7) Arachidonic acid

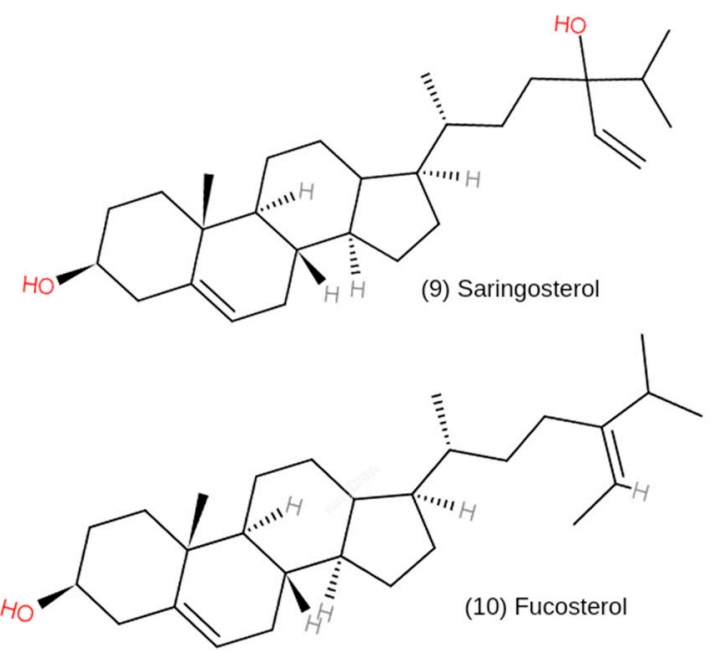

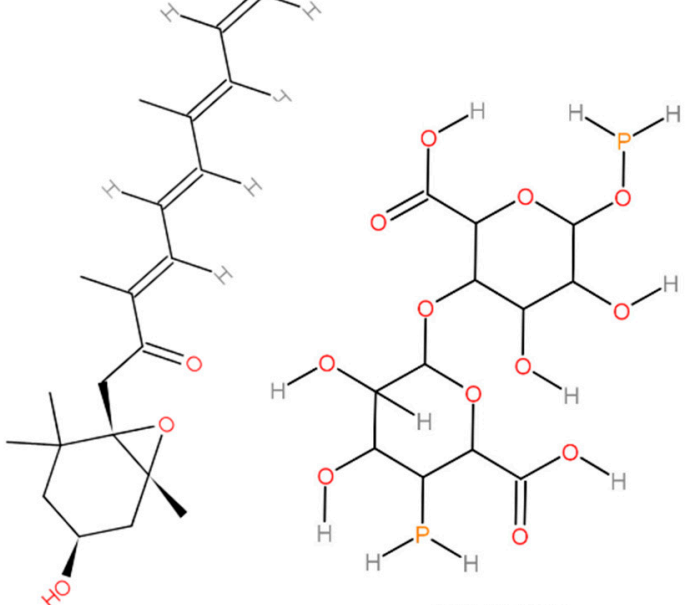

(11) Alginate

Figure 6. The chemical structures of bioactive compounds in H. fusiformis. (1) phlorotannins; (2) glycyrrhizin; (3) tetradecanoic acid; (4) palmitic acid; (5) 9-hexadecenoic acid; (6) phytol; (7) arachidonic acid; (8) fucoxanthin; (9) saringosterol; (10) fucosterol; (11) alginate; (12) lectin.

Fucoxanthin (Fx) is an allenic carotenoid extracted from edible brown seaweeds [87]. Carotenoid in terrestrial plants is predominantly found as $\beta$-carotene and lycopene [88]. Unlike carotenoid in terrestrial plants, Fx is a xanthophyll with a unique structure that includes an uncommon allenic link and a 5,6-monoepoxide in its molecule [89]. The Fx 
found in H. fusiformis has previously been categorized as a non-polar component isolated from methanol extracts [71]. Moreover, Dai et al. [90] reported that extracts of the fucoxanthin-rich fraction (FxRF) from $H$. fusiformis consisted of five pigments: Fx, chlorophyll-a, $\beta$-carotene, cis-fucoxanthin, and pheophytin-a. These pigments have also been found in other brown seaweeds. Since seaweeds have low Fx contents $(0.02-0.58 \%$ fresh weight), obtaining sufficient quantities of $\mathrm{Fx}$ for commercial applications is a significant challenge [91]. However, FxRF extracts, which contain Fx and other similar bioactive pigments, are easily obtained [8].

Another group of bioactive compounds present in H. fusiformis are alginates. Alginates are linear block co-polymers composed of a 1,4-linked $\beta$-D-mannuronic acid (M) with a $4 \mathrm{C} 1$ ring conformation and an $\alpha$-L-guluronic acid $(\mathrm{G})$ with a $4 \mathrm{C} 1$ conformation, both in the pyranose conformation and present in varying amounts in the polymer structure [92]. Natural alginates have no regular repeating sequences, and the monomers can be arranged in homogeneous blocks of varying lengths (G-, M-, and MG-blocks) or in random patterns [93]. Cong et al. [93] demonstrated that $H$. fusiformis alginates were rich in $\mathrm{M}$ blocks and the average molecular weights of 04S2P-S and commercial alginate (Alg-S) were $55.5 \mathrm{kDa}$ and $557 \mathrm{kDa}$, respectively. Sulfation modification of Alg-S resulted in higher molecular weights. Moreover, the polymer composition, as measured by the M/G ratio, particularly the length of the G-block, is critical in determining the physicochemical properties of alginate [94]. In the presence of divalent cations such as calcium, barium, and strontium, G-blocks can create strong hydrogels via coordination of the divalent cations in cavities formed by two contiguous G-blocks [93].

According to the literature, H. fusiformis contains lectins (HFL; molecular weight, $16.1 \mathrm{kDa}$ ), which are made up of monosaccharide units such as glucose, galactose, and fucose linked by N-glucosidic bonds [72]. Lectins are glycoproteins that are known for their aggregation and high specificity in binding to carbohydrates without initiating modifications via associated enzymatic activation [95]. Compared to other plant-derived lectins, lectins derived from algae have not been well characterized [96]. However, algal lectins have been shown to have mitogenic, cytotoxic, antibacterial, antinociceptive, antiinflammatory, antiviral (HIV-1), platelet aggregation, and anti-adhesion properties [97]. The chemical structures of bioactive compounds in H. fusiformis are shown in Figure 6.

\subsection{Pharmacological Properties}

H. fusiformis extract has been studied by modern researchers because of its long history of use and bioactive compounds, making it a promising species for pharmacological applications. Evidence of the pharmacological properties of seaweed is described in this article.

\subsubsection{Antibacterial Activity}

Studies on the antibacterial activity of $H$. fusiformis against selected human pathogens such as Escherichia coli, Staphylococcus aureus, Bacillus subtilis, Enterobacter aerogenes, Shewanella sp., C. vilaceum, A. hydrophilia, V. parahaemolyticus, and P. aeruginosa have been reported (Table 5).

Table 5. Summary of the antibacterial activity of $H$. fusiformis.

\begin{tabular}{|c|c|c|c|c|c|}
\hline $\begin{array}{l}\text { Experimental } \\
\text { Models }\end{array}$ & $\begin{array}{l}\text { Extract or } \\
\text { Constituent }\end{array}$ & Study Type & Microorganism & Effects & Ref \\
\hline nd & Phenolic Content & In vitro & $\begin{array}{l}\text { Escherichia coli } \\
\text { Staphylococcus aureus } \\
\text { Bacillus subtilis } \\
\text { Enterobacter aerogenes } \\
\text { Shewanella sp. }\end{array}$ & $\begin{array}{l}\text { Methanol extracts of } H \text {. fusiformis from } \\
\text { Zhoushan and Mazu against } E \text {. coli } \\
\text { showed moderate inhibitory activity } \\
\text { (11-16 mm) } \\
\text { Ethanol extract of } H \text {. fusiformis from } \\
\text { Naozhou showed moderate inhibitory } \\
\text { activity }(11-16 \mathrm{~mm}) \text { against } B \text {. subtilis }\end{array}$ & [98] \\
\hline
\end{tabular}


Table 5. Cont.

\begin{tabular}{|c|c|c|c|c|c|}
\hline $\begin{array}{l}\text { Experimental } \\
\text { Models }\end{array}$ & $\begin{array}{l}\text { Extract or } \\
\text { Constituent }\end{array}$ & Study Type & Microorganism & Effects & Ref. \\
\hline $\begin{array}{c}\text { Caenorhabditis } \\
\text { elegans }\end{array}$ & Phlorotannins & $\begin{array}{l}\text { In vitro and } \\
\text { in vivo }\end{array}$ & $\begin{array}{l}\text { Chromobacterium } \\
\text { violaceum } \\
\text { E. coli } \\
\text { S. aureus } \\
\text { Aeromonas hydrophilia } \\
\text { Vibrio parahaemolyticus } \\
\text { Pseudomonas aeruginosa }\end{array}$ & $\begin{array}{l}\text { In vitro: inhibited the anti-quorum } \\
\text { sensing (QS) activities at } 0.04858 \mathrm{~g} / \mathrm{mL} \text {, } \\
\text { reduced virulence factor production and } \\
\text { biofilm formation. In vivo: increased } \\
\text { survival rate of } P \text {. aeruginosa-infected } C \text {. } \\
\text { elegans to }>80 \% \text { during the first } 4 \text { days of } \\
\text { treatment }\end{array}$ & [99] \\
\hline
\end{tabular}

nd, not determined.

Wu et al. [98] investigated the antibacterial activity of $H$. fusiformis extract. In vitro studies of seaweed phenols showed that the methanolic extract of $H$. fusiformis from Zhoushan and Mazu, exhibited high antibacterial activity against E. coli. Furthermore, the ethanolic extract of $H$. fusiformis from Naozhou showed high antibacterial activity against B. subtilis [98]. However, it should be noted that the phenolic compositions of seaweeds is influenced by several factors, including genetic and environmental factors [100].

Furthermore, in vitro antimicrobial studies showed that phlorotannin extracted from $H$. fusiformis exhibited anti-quorum sensing (QS) activity against Chromobacterium violaceum by reducing the production of the purple pigment. Additionally, phlorotannin reduces virulence factor production and biofilm formation. Moreover, phlorotannin can reduce mortality caused by Pseudomonas aeruginosa infection in Caenorhabditis elegans in vitro [99]. However, clinical studies on the antibacterial activity of $H$. fusiformis have not been conducted.

\subsubsection{Antioxidant Activity}

The defense mechanism of organisms against free radical attack is mediated by antioxidants [101]. Antioxidants possess free radical scavenging properties, which can delay and ameliorate cell damage. There have been several studies on the antioxidant activity of $H$. fusiformis in different in vitro models, such as sheep erythrocytes [72], Vero cells [46,102], liver tissue [9,103], and RAW 264.7 macrophages [4], and in in vivo models, such as zebrafish embryos and mice [46,102-104] (Table 6).

Table 6. Summary of the antioxidant activity of $H$. fusiformis.

\begin{tabular}{|c|c|c|c|c|c|c|}
\hline $\begin{array}{l}\text { Experimental } \\
\text { Models }\end{array}$ & $\begin{array}{c}\text { Extract or } \\
\text { Constituent }\end{array}$ & $\begin{array}{l}\text { Antioxidant } \\
\text { Assay }\end{array}$ & $\begin{array}{l}\text { Scavenging } \\
\text { Activity (\%) }\end{array}$ & Study Type & Effects & Ref \\
\hline $\begin{array}{l}\text { Sheep } \\
\text { erythrocytes }\end{array}$ & Lectin & $\begin{array}{c}\text { Hemagglutination, } \\
\text { DPPH, hydroxyl, } \\
\text { and ABTS+ }\end{array}$ & $\begin{array}{c}\text { Hydroxyl: } 33.65 \% \\
\text { and DPPH: } \\
77.23 \%\end{array}$ & In vitro & $\begin{array}{c}\text { Showed free radical } \\
\text { scavenging activity } \\
\text { against hydroxyl, } \\
\text { DPPH, and ABTS+ } \\
\text { radicals }\end{array}$ & [72] \\
\hline $\begin{array}{l}\text { Vero cells and } \\
\text { zebrafish } \\
\text { embryos }\end{array}$ & Fucoidan & $\begin{array}{c}\text { DPPH, alkyl, and } \\
\text { hydroxyl }\end{array}$ & $>80 \%$ & $\begin{array}{l}\text { In vitro and } \\
\text { in vivo }\end{array}$ & $\begin{array}{l}\text { In vitro: reduced ROS } \\
\text { level, increased cell } \\
\text { viability, and } \\
\text { inhibited cleavage } \\
\text { caspase-3. In vivo: } \\
\text { reduced ROS } \\
\text { generation and lipid } \\
\text { peroxidation }\end{array}$ & [102] \\
\hline $\begin{array}{l}\text { Vero cells and } \\
\text { zebrafish } \\
\text { embryos }\end{array}$ & Fucoidan & $\begin{array}{l}\text { DPPH, hydroxyl, } \\
\text { and alkyl }\end{array}$ & $\leq 80 \%$ & $\begin{array}{l}\text { In vitro and } \\
\text { in vivo }\end{array}$ & $\begin{array}{l}\text { In vitro: Reduced } \\
\text { apoptosis. In vivo: } \\
\text { increased the survival } \\
\text { rate and decreased } \\
\text { the heart rate }\end{array}$ & [46] \\
\hline
\end{tabular}


Table 6. Cont

\begin{tabular}{|c|c|c|c|c|c|c|}
\hline $\begin{array}{l}\text { Experimental } \\
\text { Models }\end{array}$ & $\begin{array}{c}\text { Extract or } \\
\text { Constituent }\end{array}$ & $\begin{array}{c}\text { Antioxidant } \\
\text { Assay }\end{array}$ & $\begin{array}{l}\text { Scavenging } \\
\text { Activity (\%) }\end{array}$ & Study Type & Effects & Ref \\
\hline $\begin{array}{l}\text { Liver tissues and } \\
\text { ICR mice }\end{array}$ & $\begin{array}{c}\text { Sulfated } \\
\text { polysaccharides }\end{array}$ & $\begin{array}{l}\text { DPPH and } \\
\text { hydroxyl }\end{array}$ & $100 \%$ & $\begin{array}{l}\text { In vitro and } \\
\text { in vivo }\end{array}$ & $\begin{array}{l}\text { In vitro: Exhibited } \\
\text { free radical } \\
\text { scavenging activity } \\
\text { and enhanced cell } \\
\text { viability. In vivo: } \\
\text { enhanced } \\
\text { cytoprotective } \\
\text { potential via } \\
\text { upregulation of the } \\
\text { Nrf2 signaling } \\
\text { pathway }\end{array}$ & [9] \\
\hline $\begin{array}{l}\text { BALB/c mice and } \\
\text { Liver tissues }\end{array}$ & $\begin{array}{l}\text { Water-soluble } \\
\text { polysaccharides }\end{array}$ & $\begin{array}{l}\text { DPPH and } \\
\text { hydroxyl }\end{array}$ & $\begin{array}{c}\text { DPPH: }>20 \text { to } \\
\leq 70 \% \text { and } \\
\text { hydroxyl: } \geq 20 \text { to } \\
\leq 100 \%\end{array}$ & $\begin{array}{l}\text { In vitro and } \\
\text { in vivo }\end{array}$ & $\begin{array}{l}\text { In vitro: showed free } \\
\text { radical scavenging } \\
\text { activity against } \\
\text { hydroxyl and DPPH } \\
\text { radicals. In vivo: } \\
\text { reduced the MDA } \\
\text { level and elevation of } \\
\text { hepatic SOD activity }\end{array}$ & {$[103]$} \\
\hline $\begin{array}{l}\text { RAW } 264.7 \\
\text { macrophages }\end{array}$ & $\begin{array}{l}\text { Phenolic } \\
\text { compounds }\end{array}$ & $\mathrm{DPPH}$ & $<100 \%$ & In vitro & $\begin{array}{c}\text { Protective effect } \\
\text { against oxidant and } \\
\text { inflammatory activity }\end{array}$ & [4] \\
\hline ICR male mice & Polysaccharide & nd & nd & In vivo & $\begin{array}{c}\text { Stimulated } \\
\text { antioxidant enzymes } \\
\text { against free radicals }\end{array}$ & {$[104]$} \\
\hline C. elegans & Fucosterol & nd & nd & In vivo & $\begin{array}{c}\text { Prolonged the } \\
\text { lifespan of C. elegans }\end{array}$ & {$[105]$} \\
\hline
\end{tabular}

nd, not determined.

Wu et al. [72] confirmed the presence of a thyroglobulin-binding lectin in H. fusiformis using the hemagglutination inhibition test. HFL showed free radical scavenging activity against hydroxyl, DPPH, and ABTS+ radicals in sheep erythrocytes. Based on these indicators, it was concluded that $H$. fusiformis has antioxidant properties. These findings are new because algal lectins have really been reported to possess antioxidant activity, especially brown seaweed [72].

Fucoidan is a sulfate-rich polysaccharide complex found in seaweeds and has antioxidant properties. Fucoidan induces apoptosis via a mitochondria-mediated pathway [46,102]. This evidence is reinforced by a decrease in the levels of ROS and cleaved caspase-3 (cell death regulator) and an increase in the cell viability against azobis (2amidinopropane) dihydrochloride (AAPH)-induced Vero cells at all concentrations (18.75, $37.5,75$, and $150 \mu \mathrm{g} / \mathrm{mL}$ ) in vitro. Fucoidan also reduced ROS generation and lipid peroxidation in zebrafish embryos in vivo [102]. Furthermore, fucoidan can increase the survival rate and decrease the heart rate of zebrafish, indicating a protective effect against $\mathrm{H}_{2} \mathrm{O}_{2}$-induced damage and heart-beating disorder. [46].

The polysaccharide content in $\mathrm{H}$. fusiformis showed protective effects against free radicals via upregulation of the Nrf2 signaling pathway. Moreover, they can significantly reduce the malondialdehyde (MDA) level and elevation of hepatic superoxide dismutase (SOD) activity in vivo $[9,103,104]$. Additionally, phenolic compounds and fucosterol stimulate antioxidant enzymes against free radicals, thus prolonging the lifespan of $C$. elegans $[4,105]$. These findings may be beneficial in the development of pharmaceutical drugs.

\subsubsection{Anticancer and Antitumor Activity}

Several studies have reported that ethanol extracts of $H$. fusiformis, fucoidan, and alginate isolated from $H$. fusiformis possess anti-apoptotic effects $[7,10,106]$ (Table 7). 
Table 7. Summary of the anticancer and antitumor activities of $H$. fusiformis.

\begin{tabular}{|c|c|c|c|c|c|}
\hline $\begin{array}{l}\text { Experimental } \\
\text { Models }\end{array}$ & $\begin{array}{c}\text { Extract or } \\
\text { Constituent }\end{array}$ & Study Type & Optimum Dose & Effects & Ref. \\
\hline $\begin{array}{l}\text { B16F10 mouse } \\
\text { melanoma cells }\end{array}$ & Ethanol extract & In vitro & $400 \mu \mathrm{g} / \mathrm{mL}$ & $\begin{array}{l}\text { Activated the intrinsic and } \\
\text { extrinsic apoptotic pathways } \\
\text { and the ROS-dependent } \\
\text { pathway inactivated the } \\
\text { PI3K/Akt signaling }\end{array}$ & [106] \\
\hline $\begin{array}{l}\text { Human prostate } \\
\text { cancer PC } 3 \text { cells }\end{array}$ & Ethanol extracts & In vitro & $100 \mu \mathrm{g} / \mathrm{mL}$ & $\begin{array}{c}\text { Suppressed PC3 cells growth } \\
\text { and apoptosis via regulating a } \\
\text { ROS-dependent pathway }\end{array}$ & [107] \\
\hline $\begin{array}{l}\text { Hep3B human liver } \\
\text { cancer cell line }\end{array}$ & Fucoidan & In vitro & $50 \mu \mathrm{g} / \mathrm{mL}$ & Reduced Hep3B cell growth & [7] \\
\hline $\begin{array}{l}\text { Bel7402, SMMC7721, } \\
\text { Huh7, HT-29 and } \\
\text { Caco-2 cells }\end{array}$ & Alginate & In vitro & nd & $\begin{array}{c}\text { Inhibited the cell growth of } \\
\text { Bel7402, SMMC7721, and HT-29 } \\
\text { cell lines }\end{array}$ & {$[10]$} \\
\hline $\begin{array}{l}\text { Chang liver cells and } \\
\text { zebrafish embryos }\end{array}$ & Fucoidan & In vitro and in vivo & $100 \mu \mathrm{g} / \mathrm{mL}$ & $\begin{array}{l}\text { In vitro: increased the viability } \\
\text { of cells, decreased ROS levels, } \\
\text { and inhibited apoptosis. } \\
\text { In vivo: suppressed cell death } \\
\text { and ROS production }\end{array}$ & [108] \\
\hline $\begin{array}{c}\text { Human } \\
\text { microvascular } \\
\text { endothelial cells } \\
\text { (HMEC-1) and mice }\end{array}$ & Fucoidan & In vitro and in vivo & nd & $\begin{array}{l}\text { Interfered VEGF-induced } \\
\text { angiogenesis }\end{array}$ & {$[53]$} \\
\hline $\begin{array}{l}\text { HT1080 Human } \\
\text { fibrosarcoma cells }\end{array}$ & $\begin{array}{c}\text { H. fusiformis crude } \\
\text { extract }\end{array}$ & In vitro & $50 \mu \mathrm{g} / \mathrm{mL}$ & $\begin{array}{l}\text { Inhibited MMP activity and } \\
\text { intracellular MMP pathways } \\
\text { via regulation of TIMP } \\
\text { expression }\end{array}$ & [109] \\
\hline $\begin{array}{c}\text { Human } \\
\text { hepatocellular } \\
\text { carcinoma (HepG2) } \\
\text { cells and mice }\end{array}$ & Polysaccharide & In vitro and in vivo & $2000 \mu \mathrm{g} / \mathrm{mL}$ & $\begin{array}{l}\text { In vitro: demonstrated a high } \\
\text { level of cytotoxicity against } \\
\text { HepG } 2 \text { cells. In vivo: } \\
\text { significantly decreased the } \\
\text { tumor growth }\end{array}$ & [52] \\
\hline
\end{tabular}

nd, not determined.

Apoptosis, or programmed cell death, is tightly controlled at the gene level, resulting in the orderly and efficient removal of damaged cells, such as those that occur after DNA damage or during development [110]. Apoptosis may be caused by both internal and external signals, such as genotoxic stress or the binding of ligands to cell surface death receptors [111]. Cancer and tumors are characterized by the downregulation of the apoptotic cell death machinery [112].

Recent studies have shown that the ethanol extract of $H$. fusiformis has potential anticancer activity. The mechanism is mediated by activation of the intrinsic and extrinsic apoptotic pathways; thus, ROS-dependent inactivation of PI3K/Akt signaling through apoptosis was induced in B16F10 mouse melanoma cells [106]. Similar results showed that the ethanol extract of $H$. fusiformis markedly suppressed the growth of PC3 cells by regulating the ROS-dependent pathway [107]. Moreover, fucoidan potentially exhibits protective activity against cell-induced apoptosis in Hep3B cells and Chang liver cells in vitro, and suppressed cell death and ROS production in zebrafish embryos in vivo $[7,102,108]$. Further studies indicated that fucoidan may also inhibit lung cancer cells both in vitro and in vivo by interfering with VEGF-induced angiogenesis. Fucoidan was able to block the VEGFR2/Erk/VEGF signaling pathway in HMEC-1 and inhibit cancer cell growth in mice, while demonstrating its anti-angiogenic activity [53]. Additionally, Chong et al. [10] compared alginate (Alg-S) and alginates from other brown algae (04S2P-S) and found that Alg-S had a high anti-angiogenic effect on HMEC-1 cells. Among the five different tumor cells, 04S2P-S exhibited strong antitumor activity against Bel7402 only, whereas Alg-S possessed antitumor activity against three tumor cell lines, including Bel7402, SMMC7721, and HT-29 cell lines [10]. Furthermore, Lee et al. [109] demonstrated that the H. fusiformis 
solvent-partitioned fractions inhibits MMP activity and intracellular MMP pathways by regulating TIMP expression in HT1080 human fibrosarcoma cells. The antitumor effect of H. fusiformis is strengthened because it has a high level of cytotoxicity against HepG2 cells. H. fusiformis significantly inhibited tumor growth in nude mice in vivo [52]. These findings indicated that $H$. fusiformis has the potential to be used as a chemopreventive and/or adjuvant chemotherapeutic drug for the treatment of cancer and tumors.

\subsubsection{Anti-Inflammatory Activity}

Inflammation is a complex defense mechanism that seeks to restore normal cell structure and function in response to microbial and endotoxin infections, wounds, and irritants [113]. Various studies have been published on the anti-inflammatory potency of $H$. fusiformis (Table 8).

Table 8. Summary of the anti-inflammatory activity of $H$. fusiformis.

\begin{tabular}{|c|c|c|c|c|c|}
\hline $\begin{array}{l}\text { Experimental } \\
\text { Models }\end{array}$ & $\begin{array}{l}\text { Extract or } \\
\text { Constituent }\end{array}$ & Study Type & Optimum Dose & Effects & Ref. \\
\hline $\begin{array}{c}\text { RAW264.7 } \\
\text { macrophages, HaCaT } \\
\text { keratinocytes, and } \\
\text { zebrafish embryos }\end{array}$ & Fucoxanthin & In vitro and in vivo & $100 \mu \mathrm{g} / \mathrm{mL}$ & $\begin{array}{l}\text { In vitro: decreased cell viability } \\
\text { and cytokine levels. In vivo: } \\
\text { decreased nitric oxide (NO), } \\
\text { ROS, and cell death }\end{array}$ & [8] \\
\hline RAW 264.7 cells & HF extract & In vitro & $250 \mu \mathrm{g} / \mathrm{mL}$ & $\begin{array}{c}\text { Inhibited iNOS expression, } \\
\text { NF-kB translocation, activated } \\
\text { MAPKs, and STAT1 } \\
\text { phosphorylation }\end{array}$ & [114] \\
\hline $\begin{array}{l}\text { RAW } 264.7 \text { cells and } \\
\text { NC/Nga male mice }\end{array}$ & Fucosterol & In vitro and in vivo & $50 \mu \mathrm{g} / \mathrm{mL}$ & $\begin{array}{l}\text { In vitro: reduced NO } \\
\text { production. In vivo: regulated } \\
\text { the Th1/Th2 immune balance } \\
\text { and reduced systemic } \\
\text { inflammation }\end{array}$ & [115] \\
\hline Male BALB/c mice & $\begin{array}{c}\text { Ethyl acetate (EA) } \\
\text { extract }\end{array}$ & In vitro and in vivo & $100 \mu \mathrm{g} / \mathrm{mL}$ & $\begin{array}{l}\text { In vitro: inhibited activation of } \\
\mathrm{T} \text { cell activation by eliminating } \\
\text { NFAT dephosphorylation. } \\
\text { In vivo: inhibited activation of } \\
\mathrm{T} \text { cell activation by suppressing } \\
\text { Th cell-dependent cytokines }\end{array}$ & [116] \\
\hline $\mathrm{BALB} / \mathrm{c}$ mice & HF extract & In vivo & nd & $\begin{array}{l}\text { Suppressed T-helper type } 2 \\
\text { cytokine production (IL-13) }\end{array}$ & [117] \\
\hline $\begin{array}{l}\text { Macrophage cell line } \\
\text { RAW } 264.7\end{array}$ & Phlorotannin & In vitro & $43.3 \mu \mathrm{g} / \mathrm{mL}$ & $\begin{array}{l}\text { Inhibited the production of } \\
\text { pro-inflammatory mediators }\end{array}$ & [66] \\
\hline
\end{tabular}

nd, not determined.

Fucoxanthin, a bioactive compound in seaweed, decreased cell viability by $60 \%$ and cytokine levels in macrophages and keratinocytes by inhibiting the MAPK pathway, indicating its therapeutic effect during inflammation. Moreover, in particulate matter (PM)exposed zebrafish embryos, fucoxanthin significantly reduced the expression levels of factors involved in inflammatory responses and cell death, including $\mathrm{NO}$ and reactive oxygen species [8]. Previous reports have shown that $H$. fusiformis extract decreases iNOS expression and NF-KB translocation, and increases the activation of MAPKs and STAT1 phosphorylation [114].

The release of various inflammatory mediators has been linked to the progression of several inflammatory diseases, including atopic dermatitis and allergic rhinitis. Atopic dermatitis is a chronic inflammatory skin disease characterized by immunoglobulin E (IgE) antibodies and helper T cells that contain type 2 (Th2) cytokines associated with cutaneous hyper-reactivity to environmental stimuli, triggering inflammation [118]. Furthermore, $H$. fusiformis phlorotannin remarkably inhibited the production of pro-inflammatory mediators, including nitric oxide (NO), interleukin-6 (IL-6), prostaglandin E2 (PGE2), and tumor necrosis factor- $\alpha$ (TNF- $\alpha$ ) [66]. Oral administration of fucosterol $(200 \mathrm{mg} / \mathrm{kg}$ weight/day) extracted from $H$. fusiformis was reported to reduce systemic inflammation effects in 2,4- 
dinitrochlorobenzene (DNCB)-induced AD-like lesions in NC/Nga mice by regulating the Th1/Th2 immune balance [115]. Ho et al., demonstrated that the final fraction (F2') from $H$. fusiformis contained a higher proportion of butanoic acid, which could be a strong candidate for anti-atopic dermatitis. They evaluated induced AD damage in male BALB/c mice and found that the dephosphorylation of nuclear factor of activated T cells (NFAT) was inhibited in an electrophoretic mobility shift assay. As a result, cytokines produced by helper $T$ cells, such as interleukin-2,-4, and interferon- $\gamma$, were significantly reduced while the cells were activated [116]. Additionally, H. fusiformis treatment in mouse models challenged with allergic rhinitis inflammation showed anti-inflammatory and anti-allergic effects by suppressing T-helper type 2 cytokine production (IL-13) both locally and systemically; goblet cell hyperplasia OVA-specific IgE formation, and eosinophilic infiltration were all reduced [117]. These properties of $H$. fusiformis may be beneficial for the treatment of atopic and allergic diseases.

\subsubsection{Photoprotective Activity}

Plants and other autotrophic organisms are known to have photoprotective mechanisms, which are biochemical processes that protect against sun radiation by preventing the skin from oxidative stress. Sun radiation contains a variety of electromagnetic spectra, including UV rays, which can cause skin cancer from excessive exposure [119]. Numerous studies on the photoprotective potential of $H$. fusiformis-derived compounds against ultraviolet irradiation have been published [23,120-122] (Table 9).

Table 9. Summary of photoprotective activity of $H$. fusiformis.

\begin{tabular}{|c|c|c|c|c|c|}
\hline $\begin{array}{l}\text { Experimental } \\
\text { Models }\end{array}$ & $\begin{array}{l}\text { Extract or } \\
\text { Constituent }\end{array}$ & Study Type & Optimum Dose & Effects & Ref. \\
\hline $\begin{array}{l}\text { Human dermal } \\
\text { fibroblast (HDF) cells } \\
\text { exposed to UVB (50 } \\
\left.\mathrm{mJ} / \mathrm{cm}^{2}\right) \text { and } \\
\text { zebrafish larvae }\end{array}$ & Fucoidan & In vitro and in vivo & $\leq 50 \mu \mathrm{g} / \mathrm{mL}$ & $\begin{array}{c}\text { In vitro: suppressed cell death, } \\
\text { MMPs, PGE2, and } \\
\text { pro-inflammatory cytokines and } \\
\text { elevated collagen. In vivo: reduced } \\
\text { ROS levels and } \\
\text { inflammatory responses }\end{array}$ & {$[120]$} \\
\hline $\begin{array}{l}\text { RAW } 264.7 \text { cell line } \\
\text { and B16F10 cell line }\end{array}$ & $\begin{array}{l}\text { Crude sulfated } \\
\text { polysaccharides }\end{array}$ & In vitro & $100 \mu \mathrm{g} / \mathrm{mL}$ & $\begin{array}{l}\text { Inhibited lipopolysaccharide } \\
\text { (LPS)-induced inflammation, and } \\
\text { reduced } \\
\text {-MSH-stimulated melanogenesis. }\end{array}$ & {$[121]$} \\
\hline $\begin{array}{l}\text { Normal human } \\
\text { dermal fibroblasts } \\
\text { (NHDFs) }\end{array}$ & Fucosterol & In vitro & nd & $\begin{array}{l}\text { Reduced the UVB- induced } \\
\text { expression of MMP-1, IL- } 6 \text {, p-c-Jun, } \\
\text { and p-c-Fos, and increased type I } \\
\text { procollagen expression }\end{array}$ & [23] \\
\hline $\begin{array}{l}\text { Human keratinocytes } \\
\text { (HaCaT cells) and } \\
\text { B16F10 melanoma } \\
\text { cells }\end{array}$ & Fucoidan & In vitro & $100 \mu \mathrm{g} / \mathrm{mL}$ & $\begin{array}{l}\text { Reduced ROS levels, enhanced cell } \\
\text { viability, suppressed UVB-induced } \\
\text { apoptosis in HaCaT cells and } \\
\text { inhibited melanin biosynthesis }\end{array}$ & [122] \\
\hline $\begin{array}{l}\text { Human dermal } \\
\text { fibroblasts }\end{array}$ & $\begin{array}{c}\text { Sulfated } \\
\text { polysaccharides }\end{array}$ & In vitro & $\leq 50 \mu \mathrm{g} / \mathrm{mL}$ & $\begin{array}{c}\text { In vitro: suppressed cell death, } \\
\text { MMPs, PGE2, and } \\
\text { pro-inflammatory cytokines and } \\
\text { elevated collagen. In vivo: reduced } \\
\text { ROS levels and } \\
\text { inflammatory responses }\end{array}$ & [50] \\
\hline Kun Ming Mice & Polysaccharide & In vivo & $600 \mathrm{mg} / \mathrm{kg} /$ day & $\begin{array}{l}\text { Exhibited protection against UVB } \\
\text { due to decreased oxidative stress }\end{array}$ & {$[54]$} \\
\hline
\end{tabular}

nd, not determined.

Wang et al. [120] demonstrated that fucoidan treatment in HDF cells exposed to UVB $\left(50 \mathrm{~mJ} / \mathrm{cm}^{2}\right)$ exhibited protective effects in an in vitro experiment. Its effects included cell death reduction due to the scavenging of intracellular ROS, collagen synthesis, inhibition of intracellular collagenase, suppression of MMP, PGE2, and pro-inflammatory cytokine expression via the NF-B, AP-1, and MAPK pathways. Furthermore, in vivo experiments 
have shown that seaweed extracts can reduce ROS scavenging and decrease cell death in zebrafish larvae induced with UVB photodamage by reducing lipid peroxidation and inflammatory responses $[50,120]$. Additionally, fucosterol treatment significantly reduced UVB-induced expression of MMP-1, IL-6, p-c-Jun, and p-c-Fos and increased type I procollagen expression in NHDF cells [23]. In a previous study, fucoidan significantly reduced ROS levels, enhanced cell viability, and suppressed UVB-induced apoptosis in ultraviolet (UV) B-irradiated human keratinocytes (HaCaT cells [122]. Additionally, H. fusiformis extracts exhibited anti-melanogenesis effects in RAW 264.7 and B16F10 cell lines induced by ultraviolet irradiation, and decreased melanin biosynthesis by inhibiting $\alpha$-MSH-stimulated melanogenesis [121,122]. Furthermore, seaweed extract reduced oxidative stress in UVBexposed hairless Kun Ming mice by increasing superoxide dismutase (SOD) and catalase (CAT) activities, and decreasing ROS, malondialdehyde (MDA) equivalents, and matrix metalloproteinase (MMP)-1 and 9 levels [54]. These data show that $H$. fusiformis can be used as a skin-protective agent.

\subsubsection{Neuroprotective Activity}

The term "neuroinflammation" refers to an inflammatory response that is centralized within the brain or spinal cord. Some studies have examined the effect of $H$. fusiformis extract on neuroinflammation (Table 10).

Table 10. Summary of neuroprotective activity of $H$. fusiformis.

\begin{tabular}{ccccc}
\hline $\begin{array}{c}\text { Experimental } \\
\text { Models }\end{array}$ & $\begin{array}{c}\text { Extract or Chemical } \\
\text { or Constituent }\end{array}$ & Study Type & Optimum Dose & Ref. \\
\hline $\begin{array}{c}\text { BV-2 cells (mouse } \\
\text { microglia) }\end{array}$ & $\begin{array}{c}\text { H. fusiformis } \\
\text { functional oil (HFFO) }\end{array}$ & In vitro and in silico & $20 \mu \mathrm{g} / \mathrm{mL}$ & $\begin{array}{c}\text { Inhibited acetylcholinesterase } \\
\text { (AChE) and nitric oxide (NO) } \\
\text { production, reduced ROS levels }\end{array}$ \\
\hline Cell sample & Glycyrrhizin & In vitro and in silico & nd & Inhibited BACE1 activity \\
\hline $\begin{array}{c}\text { Murine BV-2 } \\
\text { microglial cells }\end{array}$ & HF extract & In vitro & $2 \mathrm{mg} / \mathrm{mL}$ & $\begin{array}{c}\text { Increased the NO levels. } \\
\text { Inhibited iNOS expression, } \\
\text { pro-inflammatory cytokines, } \\
\text { and expression of } \\
\text { NF-KB activation }\end{array}$ \\
\hline $\begin{array}{c}\text { Murine BV2 } \\
\text { microglia }\end{array}$ & Nd & In vitro & $500 \mathrm{ng} / \mathrm{mL}$ & $\begin{array}{c}\text { Suppressed LPS-induced } \\
\text { iNOS expression }\end{array}$ \\
\hline Male ICR mice & Polysaccharide & In vivo & $\mathrm{nd}$ & Improved cognitive abilities \\
\hline Male ICR mice & $\begin{array}{c}\text { H. fusiformis or its } \\
\text { extract }\end{array}$ & In vivo & $5 \mu \mathrm{gg} / \mathrm{mL}$ & $\begin{array}{c}\text { Enhanced cognition and } \\
\text { alleviated disease }\end{array}$ \\
\hline
\end{tabular}

nd, not determined.

The production of cytokines, reactive oxygen species (ROS), chemokines, and secondary messengers mediate this inflammation [126]. However, uncontrolled neuroinflammatory responses cause neuronal damage including Huntington's, Alzheimer's, and Parkinson's disease. H. fusiforme was reported to contain a neuroprotective compound: 5-hydroxy-3,6,7,8,3'4' hexamethoxyflavone (5HHMF). 5HHMF significantly inhibited lipopolysaccharide (LPS)stimulated NO production by suppressing the expression of inducible NO synthase (iNOS) in BV2 microglia [124] and inhibiting pro-inflammatory cytokines, as well as the expression of NF- $K B$ activation [123].

Several studies on the effects of $H$. fusiformis extract against Alzheimer's disease have reported that saponin and glycyrrhizin and its metabolites (18ß-glycyrrhetinic acid) inhibited $\beta$-site amyloid precursor protein cleaving enzyme 1 (BACE1). Overall, glycyrrhizin was 2- and 11-fold more effective than GLR and 18a-glycyrrhetinic acid, respectively [65]. The polysaccharide, SFPS65A, extracted from H. fusiformis, was reported to enhance the cognitive abilities of drug-treated mice in memory loss models [47]. Furthermore, a sterol (24-(S)-saringosterol) extracted from $H$. fusiformis enhanced cognition and alleviated disease by selectively activating liver $X$ receptor $\beta$ when Alzheimer's disease mice were fed with H. fusiformis or its extract [125]. Furthermore, the H. fusiformis functional oil (HFFO) 
inhibited acetylcholinesterase (AChE), NO production, and reduced the ROS levels in BV-2 cells (mouse microglia) [69].

\subsubsection{Antidiabetic Activity}

An antidiabetic substance is defined as any substance that can help patients with diabetes by controlling blood sugar levels in the body. A number of studies regarding the antidiabetic effects of $H$. fusiformis have been conducted in vitro and in vivo $[49,71,127,128]$ (Table 11).

Table 11. Summary of antidiabetic activity of $H$. fusiformis.

\begin{tabular}{ccccc}
\hline $\begin{array}{c}\text { Experimental } \\
\text { Models }\end{array}$ & $\begin{array}{c}\text { Extract or Chemical } \\
\text { or Constituent }\end{array}$ & Study Type & Optimum Dose & Effects \\
\hline $\begin{array}{c}\text { C57BL/6N muscle } \\
\text { tissue (mice) and } \\
\text { C2C12 myotube cells } \\
\text { (mice) }\end{array}$ & Polyphenols & In vitro and in vivo & $100 \mu \mathrm{g} / \mathrm{mL}$ & $\begin{array}{c}\text { In vitro: reduced } \alpha \text {-glucosidase } \\
\text { activity. In vivo: enhanced } \\
\text { muscle glucose uptake, } \\
\text { activated insulin } \\
\text { signaling-related proteins }\end{array}$ \\
\hline Male SD rats & $\begin{array}{c}\text { Polysaccharide } \\
\text { Extract }\end{array}$ & In vivo & $\begin{array}{c}\text { Improved hypoglycemic } \\
\text { activity via restoration of } \\
\text { insulin resistance and } \\
\text { mitochondrial function of } \\
\text { skeletal muscle }\end{array}$ \\
\hline $\begin{array}{c}\text { Male SD rats } \\
\text { Polysaccharide }\end{array}$ & In vivo & nd & nd & $\begin{array}{c}\text { Enhanced storage of glycogen } \\
\text { in liver and skeletal muscle and } \\
\text { suppressed gluconeogenesis }\end{array}$ \\
\hline Human recombinant & Methanol extract & In vitro & [128] \\
\hline PTP1B & Fucoidan & In vivo & nd & $\begin{array}{c}\text { PTP1B and } \\
\alpha \text {-glucosidase inhibitors }\end{array}$ \\
\hline [71] & nd & $\begin{array}{c}\text { Reduced fasting blood glucose } \\
\text { levels, diet, and water intake }\end{array}$ \\
\hline
\end{tabular}

nd, not determined.

Polyphenol suppressed $\alpha$-glucosidase activity in C57BL/6N muscle tissue (mice) in an in vitro experiment [127]. The result of an in vivo assay showed that there was an increase in muscle glucose uptake and insulin signaling-related proteins in C2C12 myotube cells (mice) fed a high-fat diet supplemented with $5 \%$ H. fusiformis for 16 weeks [127]. Polysaccharides of $H$. fusiformis possess significant hypoglycemic and hypolipidemic activities [49] and enhanced glycogen storage in the liver and skeletal muscle [128] in type 2 diabetic rats. Moreover, Seong et al., investigated the non-polar constituents of H. fusiformis that could potentially suppress glucose absorption via inhibition of the $\alpha$-glucosidase enzyme in the digestive organs and can also stimulate the insulin signaling pathway in HepG2 cells via inhibition of the PTP1B enzyme in insulin-sensitive organs [71]. Cheng et al. [55] reported that treatment with fucoidan extracts of $H$. fusiformis reduced fasting blood glucose (FBG), food and water intake and normalized the histopathological parameters of heart and liver functions in steptozotocin (STZ)-induced mice. These findings indicate that seaweed can serve as an alternative functional food that can complement the management of diabetes in the future.

\subsubsection{Immunomodulatory Effects}

Immunoprecipitation refers to interventions that cause specific changes to the immune system by increasing (immunostimulatory) or decreasing (immunosuppressive) antibody synthesis, regardless of the body's health or nutritional status. Vitamin A, C, D3, $\beta$ carotene, and other minerals found in plants may act as immunomodulators [129,130]. Several investigations have reported that $H$. fusiformis extracts, including polysaccharides, fucoidan, and fucosterol, may potentially regulate the immune system [11,51,70] (Table 12).

An in vitro study on bone marrow-derived dendritic cells (DCs) demonstrated that $H$. fusiformis extract can regulate the activation and maturation of DCs. Furthermore, there 
was an increase in splenic DC maturation and CD8+ T cell activation in mice treated with $H$. fusiformis for 3 days [131]. Additionally, the in vitro immunomodulatory activities of $H$. fusiformis polysaccharides on murine macrophages and splenocytes were investigated. In RAW 264.7 cells and splenocytes, polysaccharides exhibited potential macrophagestimulating effects, such as NO production and increased pro-inflammatory cytokines [11].

Table 12. Summary of the immunomodulatory effects of $H$. fusiformis.

\begin{tabular}{|c|c|c|c|c|c|}
\hline $\begin{array}{l}\text { Experimental } \\
\text { Models }\end{array}$ & $\begin{array}{c}\text { Extract or } \\
\text { Constituent }\end{array}$ & Study Type & Optimum Dose & Effects & Ref. \\
\hline $\begin{array}{l}\text { Dendritic cells (DCs) } \\
\text { and C57BL/6 (8 } \\
\text { weeks) mice }\end{array}$ & HF extract & In Vitro and in vivo & $5 \mu \mathrm{g} / \mathrm{mL}$ & $\begin{array}{l}\text { In vitro: induced functional and } \\
\text { phenotypical maturation of } \\
\text { DCs. In vivo: activated CD8+ T } \\
\text { cells }\end{array}$ & [131] \\
\hline $\begin{array}{l}\text { Murine macrophages } \\
\text { Raw } 264.7 \text { cells and } \\
\text { splenocytes }\end{array}$ & Polysaccharide & In vitro & $1 \mathrm{mg} / \mathrm{mL}$ & $\begin{array}{c}\text { Increased NO production and } \\
\text { pro-inflammatory cytokine } \\
\text { levels }\end{array}$ & {$[11]$} \\
\hline $\begin{array}{l}\text { Murine macrophages } \\
\text { and C57BL/6 mice }\end{array}$ & $\begin{array}{l}\text { Fucoidan and } \\
\text { fucosterol }\end{array}$ & In Vitro and in vivo & $100 \mu \mathrm{g} / \mathrm{mL}$ & $\begin{array}{l}\text { In vitro: increased production } \\
\text { of NO, secretion of tumor } \\
\text { necrosis factor- } \alpha \text { (TNF- } \alpha) \text {, and } \\
\text { phagocytosis activity. In vivo: } \\
\text { stimulated splenocyte } \\
\text { proliferation and restored the } \\
\text { level of cytokines }\end{array}$ & {$[70]$} \\
\hline $\begin{array}{c}\text { RAW } 264.7 \\
\text { macrophages and } \\
\text { C57/BL6 mice }\end{array}$ & Lipopolysac- charide & In vitro and in vivo & $5 \mu \mathrm{g} / \mathrm{mL}$ & $\begin{array}{l}\text { In vitro: increased cytokine } \\
\text { expression. In vivo: regulated } \\
\text { the immune function }\end{array}$ & [132] \\
\hline RAW264.7 cells & Polysaccharide & In vitro & nd & $\begin{array}{l}\text { Upregulated cytokine } \\
\text { production and activation of the } \\
\text { NF- } k B \text { signaling pathway }\end{array}$ & [51] \\
\hline
\end{tabular}

nd, not determined.

Park et al. [70] investigated differences in the immunostimulatory activities of enzymemodified $H$. fusiforme extracts $(\mathrm{EH})$ and normal $H$. fusiforme extracts $(\mathrm{NH})$ and found that EH increased TNF-secretion, NO production, and phagocytotic activity. Additionally, $H$. fusiforme extracts have been shown to increase splenocyte proliferation and restore cytokine levels in vivo.

The immunostimulatory activities of the $H$. fusiformis aqueous extract (HFAE) showed a dose-dependent manner; HFAE stimulated RAW 264.7 macrophages to produce cytokines such as NO, TNF- $\alpha$, IL-1 $\beta$, and IL-6, and increased their mRNA expression. Moreover, stimulated RAW 264.7 macrophages secreted NO by inducing iNOS protein expression. Furthermore, HFAE promoted the proliferation and induction of IL-2 and TNF- $\alpha$ protein expression in spleen cells [132]. A similar study by Chen et al., showed that polysaccharides can upregulate cytokine production and activate the NF- $\mathrm{kB}$ signaling pathway via CD14/IKK and P38 Axes in RAW264.7 cells [51].

\subsubsection{Osteoprotective Activity}

Osteoarthritis (OA), a widely known type of arthritis, is a degenerative joint disease characterized by joint pain and swelling caused by the gradual loss of articular cartilage. Age, sex, family history, joint stress, and obesity are major risk factors for OA. It can reduce the quality of life by interfering with daily activities and causes movement disorders [133]. Bioactive compounds contained in plants and seaweed are thought to be able to prevent osteo-disease and act as osteoprotective agents. Several studies have demonstrated the osteoprotective activity of $H$. fusiformis both in vivo and in vitro, in mice (Table 13).

Kwon et al. [12] reported that a $20 \%$ ethanol extract of $H$. fusiformis inhibited anabolic, catabolic, and genetic factors of osteoarthritis in cartilage cells and osteoarthritis-induced SD rats both in vitro and in vivo. Additionally, Lee et al. [13] reported decreased bone loss, 
reduced articular cartilage inflammation, and increased cytokine levels in fucoidan-treated rats previously injected with monosodium iodoacetate (MIA).

Table 13. Summary of osteoprotective activity of $H$. fusiformis.

\begin{tabular}{|c|c|c|c|c|c|}
\hline $\begin{array}{l}\text { Experimental } \\
\text { Models }\end{array}$ & $\begin{array}{l}\text { Extract or } \\
\text { Constituent }\end{array}$ & Study Type & Optimum Dose & Effects & Ref. \\
\hline $\begin{array}{l}\text { Cartilage cells and } \\
\text { Male SD rats }\end{array}$ & HF extract & In vitro and in vivo & $600-1000 \mu \mathrm{g} / \mathrm{mL}$ & $\begin{array}{l}\text { In vitro: reduced } \\
\text { pro-inflammatory cytokine } \\
\text { responses. In vivo: reduced the } \\
\text { articular cartilage damage and } \\
\text { development of OA }\end{array}$ & [12] \\
\hline Male SD rats & Fucoidan & In vivo & $100 \mathrm{mg} / \mathrm{kg}$ & $\begin{array}{l}\text { Prevented OA progression by } \\
\text { decreasing bone loss, prevented } \\
\text { articular cartilage inflammation, } \\
\text { and increased cytokine levels }\end{array}$ & {$[13]$} \\
\hline $\begin{array}{l}\text { Mouse C2C12 cells, } \\
\text { bone marrow cells, } \\
\text { zebrafish embryos, } \\
\text { ovariectomized } \\
(\mathrm{OVX}) \text { mice, mouse } \\
\text { calvarial bone }\end{array}$ & Polysaccharide & In vitro and in vivo & $200 \mu \mathrm{g} / \mathrm{mL}$ & $\begin{array}{l}\text { In vitro: enhanced osteoblast } \\
\text { differentiation via alkaline } \\
\text { phosphatase } \\
\text { (ALP) and bone morphogenetic } \\
\text { protein-2 (BMP-2) stimulation, } \\
\text { suppressed osteoclast } \\
\text { differentiation. In vivo: } \\
\text { increased BMP2a and 2b levels, } \\
\text { protected bone mass loss, and } \\
\text { increased bone regeneration }\end{array}$ & [134] \\
\hline MG63 cells & Fucosterol & In vitro & nd & $\begin{array}{l}\text { Protective activity through } \\
\text { bone-resorbent metabolic } \\
\text { bone disorders }\end{array}$ & [6] \\
\hline
\end{tabular}

nd, not determined; OA, osteoarthritis.

H. fusiformis showed beneficial osteoprotective effects in vitro by enhancing osteoblast differentiation via ALP and BMP-2 stimulation, and inhibiting osteoclast differentiation to prevent osteo-disease. Furthermore, there was an increase in BMP2a and $2 b$ levels and bone regeneration in vivo in mouse $\mathrm{C} 2 \mathrm{C} 12$ cells, bone marrow cells (male ICR mice), zebrafish embryos, and ovariectomized (OVX) mice [134]. Previous studies have indicated that fucosterol isolated from $H$. fusiformis increased the proliferation of MG63 cells in the treatment of bone-resorbent metabolic bone disorders, such as osteoporosis and periodontitis [6].

\subsubsection{Gastroprotective Activity}

Gastrointestinal disorders, including gastric mucosa, gastritis, and gastric and peptic ulcers, can be caused by organ damage caused by toxic agents. Ethanol is a common substance that can cause gastrointestinal disorders, which is commonly abused by humans, causing harm to several organs. Polysaccharides isolated from $H$. fusiformis have shown gastroprotective effects against several gastrointestinal diseases based on the existing literature (Table 14).

Table 14. Summary of the gastroprotective activity of $H$. fusiformis.

\begin{tabular}{|c|c|c|c|c|c|}
\hline $\begin{array}{l}\text { Experimental } \\
\text { Models }\end{array}$ & $\begin{array}{l}\text { Extract or } \\
\text { Constituent }\end{array}$ & Study Type & Optimum Dose & Effects & Ref. \\
\hline $\begin{array}{l}\text { IEC-6 cells and SD } \\
\text { rats }\end{array}$ & $\begin{array}{l}\text { Polysaccharide } \\
\text { Extract }\end{array}$ & In vitro and in vivo & $500 \mu \mathrm{g} / \mathrm{mL}$ & $\begin{array}{l}\text { Decreased the phosphorylation } \\
\text { of Shc and JNK }\end{array}$ & [24] \\
\hline $\begin{array}{l}\text { IEC-6 cells and SD } \\
\text { rats }\end{array}$ & $\begin{array}{l}\text { Polysaccharide } \\
\text { Extract }\end{array}$ & In vitro and in vivo & $300 \mathrm{mg} / \mathrm{kg}$ & $\begin{array}{l}\text { In vitro: reduced } \\
\text { phosphorylation of Shc. In vivo: } \\
\text { reduced total glutathione levels } \\
\text { and enhanced JNK } \\
\text { phosphorylation }\end{array}$ & [135] \\
\hline $\begin{array}{l}\text { Wistar albino adult } \\
\text { male rats }\end{array}$ & Polysaccharide & In vivo & $300 \mathrm{mg} / \mathrm{kg}$ & $\begin{array}{l}\text { Suppressed oxidative stress and } \\
\text { showed anti-inflammatory and } \\
\text { antioxidant activity }\end{array}$ & [48] \\
\hline
\end{tabular}


Several pharmaceutical products have been developed to treat gastrointestinal diseases such as ulcer hemorrhage and perforation [136], and polysaccharides extracted from $H$. fusiformis have been shown to exhibit protective effects against ethanol-induced cellular damage in vitro and in vivo. Furthermore, polysaccharides extracted from H. fusiformis reduced the total glutathione (GSH) levels and enhanced Jun N-terminal kinase (JNK) phosphorylation in IEC-6 cells exposed to alcohol [24,135]. Similarly, Sun et al., (2019) reported that ethanol-induced gastric ulcer was inhibited in rats treated with H. fusiformis polysaccharide extracts, which modified various molecules involved in the initiation of gastric ulcers [48]. These results suggest that polysaccharides extracted from $\mathrm{H}$. fusiformis could be a potential therapeutic agent for gastrointestinal diseases.

\section{Conclusions}

Based on the findings of this review, it can be concluded that $H$. fusiformis has great potential as a source of high-value compounds because of its nutritional and pharmacological properties. Although $H$. fusiformis has been used since ancient times in traditional medicine and for food, scientific studies validating and confirming its effects are still lacking. H. fusiformis contains higher amounts of major minerals (macronutrients) and trace elements (micronutrients) than terrestrial edible plants. Furthermore, some bioactive compounds isolated from $H$. fusiformis, including polysaccharides (e.g., alginate and fucoidan), polyphenols (e.g., phlorotannins), glycyrrhizin, arsenic, sterol (fucosterol, and saringosterol), pigments (e.g., carotenoid fucoxanthin), and fatty acids (e.g., tetradecanoic acid, 9-hexadecenoic acid, palmitic acid, and arachidonic acid) can be further evaluated for use as nutraceuticals and pharmaceuticals.

The nutritional and pharmacological properties of H. fusiformis are promising for industrial applications. Some strategies could be applied for the use of H. fusiformis for medicinal and nutritional purposes. The development of marine resources has challenges in terms of the supply and maintenance of the quality of nutritional value and bioactive compounds. Hence, the first strategy is to increase H. fusiformis production through economical, efficient, and sustainable cultivation methods. Presently, South China and Korea are the largest producers of $H$. fusiformis. The second strategy should involve the standardization of nutritional components and bioactive compounds isolated from H. fusiformis. The third strategy is to conduct further research on bioactive and other valuable compounds present in H. fusiformis. Although the number of studies on bioactive compounds in $H$. fusiformis has increased, especially regarding antioxidant and anticancer bioactivity, most studies are still in the preliminary stage.

Author Contributions: Conceptualization, M.D.N.M., J.-S.K. and J.-S.C.; formal analysis, M.D.N.M. and D.H.; investigation, M.D.N.M., D.H. and J.-S.C.; methodology, M.D.N.M., J.-H.S. and J.-S.C.; software, D.H.; supervision, M.D.N.M., J.-S.K. and J.-S.C.; visualization, M.D.N.M., J.-H.S. and D.H.; writing—original draft, M.D.N.M. and D.H.; writing—review and editing, M.D.N.M. and J.-S.C. All authors have read and agreed to the published version of the manuscript.

Funding: This research was funded by the Ministry of Oceans and Fisheries, Korea, under the Project no. PJT200885 entitled: "Development and commercialization of traditional seafood products based on the Korean coastal marine resources".

Institutional Review Board Statement: Not applicable.

Informed Consent Statement: Not applicable.

Data Availability Statement: Data supporting reported results are available upon request.

Conflicts of Interest: The authors declare no conflict of interest. 


\section{References}

1. Zou, D.; Liu, S.; Du, H.; Xu, J. Growth and photosynthesis in seedlings of Hizikia fusiformis (Harvey) Okamura (Sargassaceae, Phaeophyta) cultured at two different temperatures. J. Appl. Phycol. 2012, 24, 1321-1327. [CrossRef]

2. Ma, Z.; Wu, M.; Lin, L.; Thring, R.W.; Yu, H.; Zhang, X.; Zhao, M. Allelopathic interactions between the macroalga Hizikia fusiformis (Harvey) and the harmful blooms-forming dinoflagellate Karenia mikimotoi. Harmful Algae 2017, 65, 19-26. [CrossRef] [PubMed]

3. Food and Agriculture Organization of the United Nations (FAO). Genetic Resources for Farmed Seaweed; FAO: Rome, Italy, 2017; 72p.

4. Liu, N.; Fu, X.; Duan, D.; Xu, J.; Gao, X.; Zhao, L. Evaluation of bioactivity of phenolic compounds from the brown seaweed of Sargassum fusiforme and development of their stable emulsion. J. Appl. Phycol. 2018, 30, 1955-1970. [CrossRef]

5. Wang, W.; Lu, J.; Wang, C.; Wang, C.; Zhang, H.; Li, C.; Qian, G. Effects of Sargassum fusiforme polysaccharides on antioxidant activities and intestinal functions in mice. Int. J. Biol. Macromol. 2013, 58, 127-132. [CrossRef] [PubMed]

6. Huh, G.W.; Lee, D.Y.; In, S.J.; Lee, D.G.; Park, S.Y.; Yi, T.H.; Kang, H.C.; Seo, W.D.; Baek, N.I. Fucosterols from Hizikia fusiformis and their proliferation activities on osteosarcoma-derived cell MG63. J. Korean Soc. Appl. Biol. Chem. 2012, 55, 551-555. [CrossRef]

7. Dai, Y.L.; Jiang, Y.F.; Lee, H.G.; Jeon, Y.J.; Kang, M.C. Characterization and screening of anti-tumor activity of fucoidan from acid-processed hijiki (Hizikia fusiforme). Int. J. Biol. Macromol. 2019, 139, 170-180. [CrossRef] [PubMed]

8. Dai, Y.; Jiang, Y.; Lu, Y.; Yu, J.; Kang, M. Fucoxanthin-rich fraction from Sargassum fusiformis alleviates particulate matter-induced inflammation in vitro and in vivo. Toxicol. Rep. 2021, 8, 349-358. [CrossRef]

9. Chen, P.; He, D.; Zhang, Y.; Yang, S.; Chen, L.; Wang, S.; Zou, H.; Liao, Z.; Zhang, X.; Wu, M. Sargassum fusiforme polysaccharides activate antioxidant defense by promoting Nrf2-dependent cytoprotection and ameliorate stress insult during aging. Food Funct. 2016, 7, 4576-4588. [CrossRef] [PubMed]

10. Cong, Q.; Xiao, F.; Liao, W.; Dong, Q.; Ding, K. Structure and biological activities of an alginate from Sargassum fusiforme, and its sulfated derivative. Int. J. Biol. Macromol. 2014, 39, 252-259. [CrossRef] [PubMed]

11. Jeong, S.C.; Jeong, Y.T.; Lee, S.M.; Kim, J.H. Immune-modulating activities of polysaccharides extracted from brown algae Hizikia fusiforme. Biosci. Biotechnol. Biochem. 2015, 79, 1362-1365. [CrossRef]

12. Kwon, H.O.; Lee, M.; Kim, O.K.; Ha, Y.; Jun, W.; Lee, J. Effect of Hijikia fusiforme extracts on degenerative osteoarthritis in vitro and in vivo models. Nutr. Res. Pract. 2016, 10, 265-273. [CrossRef]

13. Lee, D.G.; Park, S.Y.; Chung, W.S.; Park, J.H.; Hwang, E.; Mavlonov, G.T.; Kim, I.H.; Kim, K.Y.; Yi, T.H. Fucoidan Prevents the Progression of Osteoarthritis in Rats. J. Med. Food 2015, 18, 1032-1041. [CrossRef] [PubMed]

14. Rana, Z.H.; Alam, M.K.; Akhtaruzzaman, M. Nutritional composition, total phenolic content, antioxidant and $\alpha$-amylase inhibitory activities of different fractions of selected wild edible plants. Antioxidants 2019, 8, 203. [CrossRef]

15. Alam, M.K.; Rana, Z.H.; Islam, S.N.; Akhtaruzzaman, M. Comparative assessment of nutritional composition, polyphenol profile, antidiabetic and antioxidative properties of selected edible wild plant species of Bangladesh. Food Chem. 2020, 320, 126646. [CrossRef]

16. Wijesekara, I.; Kim, S.K.; Li, Y.; Li, Y.X. Phlorotannins as bioactive agents from brown algae. Process Biochem. 2011, 46, $2219-2224$. [CrossRef]

17. Freile-Pelegrín, Y.; Robledo, D. Bioactive Phenolic Compounds from Algae. Bioact. Compd. Mar. Foods 2013, 113-129. [CrossRef]

18. Cotas, J.; Leandro, A.; Monteiro, P.; Pacheco, D.; Figueirinha, A.; Gonçalves, A.M.M.; da Silva, G.J.; Pereira, L. Seaweed phenolics, From extraction to applications. Mar. Drugs 2020, 18, 384. [CrossRef] [PubMed]

19. Siriwardhana, N.; Lee, K.W.; Kim, S.H.; Ha, J.W.; Jeon, Y.J. Antioxidant Activity of Hizikia fusiformis on Reactive Oxygen Species Scavenging and Lipid Peroxidation Inhibition. Food Sci. Technol. Int. 2003, 9, 339-346. [CrossRef]

20. Moher, D.; Liberati, A.; Tetzlaff, J.; Altman, D.G. Preferred reporting items for systematic reviews and meta-analyses, The PRISMA statement. PLoS Med. 2009, 6, e1000097. [CrossRef] [PubMed]

21. Choi, Y.J.; Lee, S.R.; Oh, J.W. Effects of dietary fermented seaweed and seaweed fusiforme on growth performance, carcass parameters and immunoglobulin concentration in broiler chicks. Asian-Australasian J. Anim. Sci. 2014, 27, 862-870. [CrossRef]

22. Zheng, T.; Liu, C.; Yang, J.; Liu, Q.; Li, J. Hijiki seaweed (Hizikia fusiformis), Nutritional value, safety concern and arsenic removal method. Adv. Mater. Res. 2013, 634-638, 1247-1252. [CrossRef]

23. Hwang, E.; Park, S.-Y.; Sun, Z.; Shin, H.-S.; Lee, D.-G.; Yi, T.H. The Protective Effects of Fucosterol Against Skin Damage in UVB-Irradiated Human Dermal Fibroblasts. Mar. Biotechnol. 2013, 16, 361-370. [CrossRef] [PubMed]

24. Choi, E.Y.; Hwang, H.J.; Nam, T.J. Protective effect of a polysaccharide from Hizikia fusiformis against ethanol-induced cytotoxicity in IEC-6 cells. Toxicol. In Vitro 2010, 24, 79-84. [CrossRef]

25. Choi, Y.S.; Kum, J.S.; Jeon, K.H.; Park, J.D.; Choi, H.W.; Hwang, K.E.; Jeong, T.J.; Kim, Y.B.; Kim, C.J. Effects of Edible Seaweed on Physicochemical and Sensory Characteristics of Reduced-salt Frankfurters. Korean J. Food Sci. Anim. Resour. 2015, 35, 748-756. [CrossRef] [PubMed]

26. Song, J.-W.; Jang, J.-W.; Kim, S.-S.; Oh, D.-H.; Cha, J.-H.; Lee, K.-J. Effect of Dietary Supplementation with Alga (Hizikia fusiformis and Ecklonia cava) on the Non-specific Immune Responses of Parrot Fish Oplegnathus fasciatus. Korean J. Fish Aquat. Sci. 2011, 44, 332-338. [CrossRef]

27. Salehi, B.; Sharifi-rad, J.; Seca, A.M.L.; Pinto, D.C.G.A. Current Trends on Seaweeds, Looking at Chemical. Molecules 2019, $24,4182$. [CrossRef] [PubMed] 
28. Holdt, S.L.; Kraan, S. Bioactive compounds in seaweed, Functional food applications and legislation. J. Appl. Phycol. 2011, 23, 543-597. [CrossRef]

29. Leandro, A.; Pacheco, D.; Cotas, J.; Marques, J.C.; Pereira, L.; Gonçalves, A.M.M. Seaweed's Bioactive Candidate Compounds to Food Industry and Global Food Security. Life 2020, 10, 140. [CrossRef]

30. Karr-Lilienthal, L.K.; Bauer, L.L.; Utterback, P.L.; Zinn, K.E.; Frazier, R.L.; Parsons, C.M.; Fahey, G.C. Chemical composition and nutritional quality of soybean meals prepared by extruder/expeller processing for use in poultry diets. J. Agric. Food Chem. 2006, 54, 8108-8114. [CrossRef] [PubMed]

31. Schmid, M.; Kraft, L.G.K.; van der Loos, L.M.; Kraft, G.T.; Virtue, P.; Nichols, P.D.; Hurd, C.L. Southern Australian seaweeds, A promising resource for omega-3 fatty acids. Food Chem. 2018, 265, 70-77. [CrossRef] [PubMed]

32. Dawczynski, C.; Schubert, R.; Jahreis, G. Amino acids, fatty acids, and dietary fibre in edible seaweed products. Food Chem. 2007, 103, 891-899. [CrossRef]

33. European Food Safety Authority. Scientific Opinion on Dietary Reference Values for carbohydrates and dietary fibre. EFSA J. 2010, 8, 1462. [CrossRef]

34. Clark, M.J.; Slavin, J.L. The effect of fiber on satiety and food intake, A systematic review. J. Am. Coll. Nutr. 2013, 32, $200-211$. [CrossRef] [PubMed]

35. Panel, E.; Nda, A. Scientific Opinion on the substantiation of health claims related to the replacement of mixtures of saturated fatty acids (SFAs) as present in foods or diets with mixtures of monounsaturated fatty acids (MUFAs) and/or mixtures of polyunsaturated fatty aci. EFSA J. 2011, 9, 2069. [CrossRef]

36. Cherry, P.; O’hara, C.; Magee, P.J.; Mcsorley, E.M.; Allsopp, P.J. Risks and benefits of consuming edible seaweeds. Nutr. Rev. 2019, 77, 307-329. [CrossRef] [PubMed]

37. Rupérez, P.; Ahrazem, O.; Leal, J.A. Potential antioxidant capacity of sulfated polysaccharides from the edible marine brown seaweed Fucus vesiculosus. J. Agric. Food Chem. 2002, 50, 840-845. [CrossRef]

38. Fouda, W.A.; Ibrahim, W.M.; Ellamie, A.M.; Ramadan, G. Biochemical and mineral compositions of six brown seaweeds collected from red sea at hurghada coast. Indian J. Geo-Mar. Sci. 2019, 48, 484-491.

39. Matanjun, P.; Mohamed, S.; Mustapha, N.M.; Muhammad, K. Nutrient content of tropical edible seaweeds, Eucheuma cottonii, Caulerpa lentillifera and Sargassum polycystum. J. Appl. Phycol. 2009, 21, 75-80. [CrossRef]

40. Mendis, E.; Kim, S.K. Present and Future Prospects of Seaweeds in Developing Functional Foods. In Advances in Food and Nutrition Research; Academic Press: New York, NY, USA, 2011; Volume 64. [CrossRef]

41. Rohani-Ghadikolaei, K.; Abdulalian, E.; Ng, W.K. Evaluation of the proximate, fatty acid and mineral composition of representative green, brown and red seaweeds from the Persian Gulf of Iran as potential food and feed resources. J. Food Sci. Technol. 2012, 49, 774-780. [CrossRef] [PubMed]

42. Wu, G.; Fanzo, J.; Miller, D.D.; Pingali, P.; Post, M.; Steiner, J.L.; Thalacker-Mercer, A.E. Production and supply of high-quality food protein for human consumption, Sustainability, challenges, and innovations. Ann. N. Y. Acad. Sci. 2014, 1321, 1-19. [CrossRef]

43. Al-fartusie, F.S.; Mohssan, S.N. Essential Trace Elements and Their Vital Roles in Human Body. Indian J. Adv. Chem. Sci. 2017, 5, 127-136. [CrossRef]

44. Garcia-Vaquero, M.; Rajauria, G.; Miranda, M.; Sweeney, T.; Lopez-Alonso, M.; O’Doherty, J. Seasonal Variation of the Proximate Composition, Mineral Content, Fatty Acid Profiles and Other Phytochemical Constituents of Selected Brown Macroalgae. Mar. Drugs 2021, 19, 204. [CrossRef] [PubMed]

45. Rupérez, P. Mineral content of edible marine seaweeds. Food Chem. 2002, 79, 23-26. [CrossRef]

46. Wang, L.; Jayawardena, T.U.; Yang, H.W.; Lee, H.G.; Kang, M.C.; Sanjeewa, K.K.A.; Oh, J.Y.; Jeon, Y.J. Isolation, characterization, and antioxidant activity evaluation of a fucoidan from an enzymatic digest of the edible seaweed, Hizikia fusiforme. Antioxidants 2020, 9, 363. [CrossRef]

47. Hu, P.; Li, Z.; Chen, M.; Sun, Z.; Ling, Y.; Jiang, J.; Huang, C. Structural elucidation and protective role of a polysaccharide from Sargassum fusiforme on ameliorating learning and memory deficiencies in mice. Carbohydr. Polym. 2016, 139, 150-158. [CrossRef] [PubMed]

48. Sun, G.; Lian, T.; Yang, B.; Yi, G.; Li, X. Ameliorative Effect of Sargassum fusiforme Polysaccharides on Oxidative Stress and Inflammation in Ethanol-induced Gastric Ulcer. Pharmacogn. Mag. 2019, 15, 244-252. [CrossRef]

49. Jia, R.B.; Li, Z.R.; Ou, Z.R.; Wu, J.; Sun, B.; Lin, L.; Zhao, M. Physicochemical Characterization of Hizikia fusiforme Polysaccharide and Its Hypoglycemic Activity via Mediating Insulin-Stimulated Blood Glucose Utilization of Skeletal Muscle in Type 2 Diabetic Rats. Chem. Biodivers. 2020, 17. [CrossRef] [PubMed]

50. Wang, L.; Oh, J.Y.; Kim, H.S.; Lee, W.W.; Cui, Y.; Lee, H.G.; Kim, Y.T.; Ko, J.Y.; Jeon, Y.J. Protective effect of polysaccharides from Celluclast-assisted extract of Hizikia fusiforme against hydrogen peroxide-induced oxidative stress in vitro in Vero cells and in vivo in zebrafish. Int. J. Biol. Macromol. 2018, 112, 483-489. [CrossRef] [PubMed]

51. Chen, L.; Chen, P.; Liu, J.; Hu, C.; Yang, S.; He, D.; Yu, P.; Wu, M.; Zhang, X. Sargassum fusiforme polysaccharide SFP-F2 activates the NF-kB signaling pathway via CD14/IKK and p38 axes in RAW264.7 cells. Mar. Drugs 2018, 16, 264. [CrossRef] [PubMed]

52. Fan, S.; Zhang, J.; Nie, W.; Zhou, W.; Jin, L.; Chen, X.; Lu, J. Antitumor Effects of Polysaccharide from Sargassum Fusiforme against Human Hepatocellular Carcinoma HepG 2 Cells. Food Chem Toxicol. 2017, 102, 53-62. [CrossRef] [PubMed]

53. Chen, H.; Cong, Q.; Du, Z.; Liao, W.; Zhang, L. Sulfated fucoidan FP08S2 inhibits lung cancer cell growth in vivo by disrupting angiogenesis via targeting VEGFR2/VEGF and blocking VEGFR2/Erk/VEGF signaling. Cancer Lett. 2016, 382, 44-52. [CrossRef] 
54. Ye, Y.; Ji, D.; You, L.; Zhou, L.; Zhao, Z.; Brennan, C. Structural properties and protective effect of Sargassum fusiforme polysaccharides against ultraviolet $B$ radiation in hairless Kun Ming mice. J. Funct. Foods 2018, 43, 8-16. [CrossRef]

55. Cheng, Y.; Sibusiso, L.; Hou, L.; Jiang, H.; Chen, P.; Zhang, X.; Wu, M.; Tong, H. Sargassum fusiforme fucoidan modifies the gut microbiota during alleviation of streptozotocin-induced hyperglycemia in mice. Int. J. Biol. Macromol. 2019, 131, 1162-1170. [CrossRef] [PubMed]

56. Zhu, T.; Heo, H.J.; Row, K.H. Optimization of crude polysaccharides extraction from Hizikia fusiformis using response surface methodology. Carbohydr. Polym. 2010, 82, 106-110. [CrossRef]

57. Torres, M.D.; Flórez-Fernández, N.; Domínguez, H. Integral utilization of red seaweed for bioactive production. Mar. Drugs 2019, 17, 314. [CrossRef] [PubMed]

58. Pierre, G.; Delattre, C.; Dubessay, P.; Jubeau, S.; Vialleix, C.; Cadoret, J.P.; Probert, I.; Michaud, P. What is in store for EPS microalgae in the next decade? Molecules 2019, 24, 4296. [CrossRef] [PubMed]

59. Stiger-Pouvreau, V.; Bourgougnon, N.; Deslandes, E. Carbohydrates from Seaweeds; Elsevier Inc.: Amsterdam, The Netherlands, 2016. [CrossRef]

60. Hentati, F.; Tounsi, L.; Djomdi, D.; Pierre, G.; Delattre, C.; Ursu, A.V.; Vendri, I.; Abdelkafi, S.; Michaud, P. Bioactive polysaccharides from seaweeds. Molecules 2020, 25, 3152. [CrossRef] [PubMed]

61. Li, B.; Lu, F.; Wei, X.; Zhao, R. Fucoidan, Structure and bioactivity. Molecules 2008, 13, 1671-1695. [CrossRef] [PubMed]

62. Wang, Y.; Xing, M.; Cao, Q.; Ji, A.; Liang, H.; Song, S. Biological activities of fucoidan and the factors mediating its therapeutic effects, A review of recent studies. Mar. Drugs 2019, 17, 183. [CrossRef]

63. García-Ríos, V.; Ríos-Leal, E.; Robledo, D.; Freile-Pelegrin, Y. Polysaccharides composition from tropical brown seaweeds. Phycol. Res. 2012, 60, 305-315. [CrossRef]

64. Ale, M.T.; Meyer, A.S. Fucoidans from brown seaweeds, An update on structures, extraction techniques and use of enzymes as tools for structural elucidation. RSC Adv. 2013, 3, 8131-8141. [CrossRef]

65. Wagle, A.; Seong, S.H.; Zhao, B.T.; Woo, M.H.; Jung, H.A.; Choi, J.S. Comparative study of selective in vitro and in silico BACE1 inhibitory potential of glycyrrhizin together with its metabolites, $18 \alpha$ - and $18 \beta$-glycyrrhetinic acid, isolated from Hizikia fusiformis. Arch. Pharm. Res. 2018, 41, 409-418. [CrossRef]

66. Yang, E.-J.; Moon, J.-Y.; Kim, M.-J.; Kim, D.S.; Kim, C.-S.; Lee, W.J.; Lee, N.H.; Hyun, C.-G. Inhibitory effect of Jeju endemic seaweeds on the production of pro-inflammatory mediators in mouse macrophage cell line RAW 264.7. J. Zhejiang Univ. Sci. B 2010, 11, 315-322. [CrossRef]

67. Park G young Kang D eun Davaatseren, M.; Shin, C.; Kang, G.J.; Chung, M.S. Reduction of total, organic, and inorganic arsenic content in Hizikia fusiforme (Hijiki). Food Sci. Biotechnol. 2019, 28, 615-622. [CrossRef]

68. Zhao, Y.F.; Wu, J.F.; Shang, D.R.; Ning, J.S.; Ding, H.Y.; Zhai, Y.X. Arsenic species in edible seaweeds using in vitro biomimetic digestion determined by high-performance liquid chromatography inductively coupled plasma mass spectrometry. Int. J. Food Sci. 2014, 2014, 436347. [CrossRef]

69. Yang, W.C.; Zhang, Y.Y.; Li, Y.J.; Nie, Y.Y.; Liang, J.Y.; Liu, Y.Y.; Liu, J.S.; Zhang, Y.P.; Song, C.; Qian, Z.J.; et al. Chemical Composition and Anti-Alzheimer's Disease-Related Activities of a Functional Oil from the Edible Seaweed Hizikia fusiforme. Chem. Biodivers. 2020, 17. [CrossRef]

70. Park, S.Y.; Hwang, E.; Shin, Y.K.; Lee, D.G.; Yang, J.E.; Park, J.H.; Yi, T.H. Immunostimulatory Effect of Enzyme-Modified Hizikia fusiforme in a Mouse Model In Vitro and Ex Vivo. Mar. Biotechnol. 2017, 19, 65-75. [CrossRef]

71. Seong, S.H.; Nguyen, D.H.; Wagle, A.; Woo, M.H.; Jung, H.A.; Choi, J.S. Experimental and Computational Study to Reveal the Potential of Non-Polar Constituents from Hizikia fusiformis as Dual Protein Tyrosine Phosphatase 1B and $\alpha$-Glucosidase Inhibitors. Mar. Drugs 2019, 17, 302. [CrossRef] [PubMed]

72. Wu, M.; Tong, C.; Wu, Y.; Liu, S.; Li, W. A novel thyroglobulin-binding lectin from the brown alga Hizikia fusiformis and its antioxidant activities. Food Chem. 2016, 201, 7-13. [CrossRef] [PubMed]

73. Akter, K.F.; Owens, G.; Davey, D.E.; Naidu, R. Arsenic speciation and toxicity in biological systems. Rev. Environ. Contam. Toxicol. 2006, 184, 97-149. [CrossRef]

74. Abernathy, C.O.; Thomas, D.J.; Calderon, R.L. Toxicity and Risk Assessment of Trace Elements. J. Nutr. 2003, 133, 1536S-1538S. [CrossRef] [PubMed]

75. Rispin, A.; Farrar, D.; Margosches, E.; Gupta, K.; Stitzel, K.; Carr, G.; Greene, M.; Meyer, W.; McCall, D. Alternative methods for the median lethal dose $(\mathrm{LD}(50))$ test, The up-and-down procedure for acute oral toxicity. ILAR J. 2002, 43, 233-243. [CrossRef] [PubMed]

76. Poma, P.; Labbozzetta, M.; Notarbartolo, M.; Bruno, M.; Maggio, A.; Rosselli, S.; Sajeva, M.; Zito, P. Chemical composition, in vitro antitumor and pro-oxidant activities of Glandora rosmarinifolia (Boraginaceae) essential oil. PLoS ONE 2018, 13, e0196947. [CrossRef] [PubMed]

77. Kim, H.-S.; Lee, S.-Y.; Kim, B.-Y.; Lee, E.-K.; Ryu, J.-H.; Lim, G.-B. Effects of modifiers on the supercritical CO2 extraction of glycyrrhizin from licorice and the morphology of licorice tissue after extraction. Biotechnol. Bioprocess Eng. 2004, 9, 447-453. [CrossRef]

78. Batiha, G.E.S.; Beshbishy, A.M.; El-Mleeh, A.; Abdel-Daim, M.M.; Devkota, H.P. Traditional uses, bioactive chemical constituents, and pharmacological and toxicological activities of Glycyrrhiza glabra L. (fabaceae). Biomolecules 2020, 10, 352. [CrossRef] 
79. Kwon, Y.J.; Son, D.H.; Chung, T.H.; Lee, Y.J. A Review of the Pharmacological Efficacy and Safety of Licorice Root from Corroborative Clinical Trial Findings. J. Med. Food 2020, 23, 12-20. [CrossRef] [PubMed]

80. Ming, L.J.; Yin, A.C.Y. Therapeutic effects of glycyrrhizic acid. Nat. Prod. Commun. 2013, 8, 415-418. [CrossRef]

81. Wang, T.; Jónsdóttir, R.; Liu, H.; Gu, L.; Kristinsson, H.G.; Raghavan, S.; Olafsdóttir, G. Antioxidant capacities of phlorotannins extracted from the brown algae Fucus vesiculosus. J. Agric. Food Chem. 2012, 60, 5874-5883. [CrossRef]

82. Meslet-Cladière, L.; Delage, L.; Goulitquer, S.; Leblanc, C.; Creis, E.; Gall, E.A.; Stiger-pouvreau, V.; Czjzek, M.; Potin, P. Structure/Function Analysis of a Type III Polyketide Synthase in the Brown Alga Ectocarpus siliculosus Reveals a Biochemical Pathway in Phlorotannin Monomer Biosynthesis. Plant Cell 2013, 25, 3089-3103. [CrossRef]

83. Li, Y.; Fu, X.; Duan, D.; Liu, X.; Xu, J.; Gao, X. Extraction and Identification of Phlorotannins from the Brown Alga, Sargassum fusiforme. Mar. Drugs 2017, 15, 49. [CrossRef]

84. Martens, N.; Schepers, M.; Zhan, N.; Leijten, F.; Voortman, G.; Tiane, A.; Rombaut, B.; Poisquet, J.; van de Sande, N.; Kerksiek, A.; et al. 24(S)-Saringosterol Prevents Cognitive Decline in a Mouse Model for Alzheimer's Disease. Mar. Drugs 2021, 19, 190. [CrossRef]

85. Schultz, J.R.; Tu, H.; Luk, A.; Repa, J.J.; Medina, J.C.; Li, L.; Schwendner, S.; Wang, S.; Thoolen, M.; Mangelsdorf, D.J.; et al. Role of LXRs in control of lipogenesis. Genes Dev. 2000, 14, 2831-2838. [CrossRef] [PubMed]

86. Chen, Z.; Liu, J.; Fu, Z.; Ye, C.; Zhang, R.; Song, Y.; Zhang, Y.; Li, H.; Ying, H.; Liu, H. 24(S)-saringosterol from edible marine seaweed Sargassum fusiforme is a novel selective LXRß agonist. J. Agric. Food Chem. 2014, 62, 6130-6137. [CrossRef]

87. Zhang, H.; Tang, Y.; Zhang, Y.; Zhang, S.; Qu, J.; Wang, X.; Kong, R.; Han, C.; Liu, Z. Fucoxanthin, A Promising Medicinal and Nutritional Ingredient. Evid. Based Complement Altern. Med. 2015, 2015, 723515. [CrossRef] [PubMed]

88. Alam, M.K.; Sams, S.; Rana, Z.H.; Akhtaruzzaman, M.; Islam, S.N. Minerals, vitamin C, and effect of thermal processing on carotenoids composition in nine varieties orange-fleshed sweet potato (Ipomoea batatas L.). J. Food Compos. Anal. 2020, $92,103582$. [CrossRef]

89. Maeda, H.; Hosokawa, M.; Sashima, T.; Miyashita, K. Antiobesity effect of fucoxanthin from edible seaweeds and its multibiological functions. ACS Symp. Ser. 2008, 993, 376-388. [CrossRef]

90. de Quirós, A.R.B.; Frecha-Ferreiro, S.; Vidal-Pérez, A.M.; López-Hernández, J. Antioxidant compounds in edible brown seaweeds. Eur. Food Res. Technol. 2010, 231, 495-498. [CrossRef]

91. Kim, S.M.; Jung, Y.J.; Kwon, O.N.; Cha, K.H.; Um, B.H.; Chung, D.; Pan, C.H. A potential commercial source of fucoxanthin extracted from the microalga Phaeodactylum tricornutum. Appl. Biochem. Biotechnol. 2012, 166, 1843-1855. [CrossRef] [PubMed]

92. Rinaudo, M. Main properties and current applications of some polysaccharides as biomaterials. Polym. Int. 2008, 57, 397-430. [CrossRef]

93. Hreggviðsson, G.Ó.; Nordberg-Karlsson, E.M.; Tøndervik, A.; Aachmann, F.L.; Dobruchowska, J.M.; Linares-Pastén, J.; DaugbjergChristensen, M.; Moneart, A.; Kristjansdottir, T.; Sletta, H.; et al. Chapter 16. Biocatalytic refining of polysaccharides from brown seaweeds. In Advanced in Green Chemistry, Sustainable Seaweed Technologies; Torres, M.D., Kraan, S., Dominguez, H., Eds.; Elsevier: Amsterdam, The Netherlands, 2020; pp. 447-504. [CrossRef]

94. George, M.; Abraham, T.E. Polyionic hydrocolloids for the intestinal delivery of protein drugs, Alginate and chitosan-A review. J. Control Release 2006, 114, 1-14. [CrossRef]

95. Weis, W.I.; Drickamer, K. Structural Basis of Recognition Lectin-Carb Ohydrate. Anna. Rev. Biochen 1996, 65, 441-473. [CrossRef] [PubMed]

96. Ziółkowska, N.E.; Wlodawer, A. Structural studies of algal lectins with anti-HIV activity. Acta Biochim. Pol. 2006, 53, 617-626. [CrossRef] [PubMed]

97. Harnedy, P.A.; Fitzgerald, R.J. Bioactive proteins, peptides, and amino acids from macroalgae. J. Phycol. 2011, 47, $218-232$. [CrossRef] [PubMed]

98. Wu, M.-J.; Wu, Y.; Tong, C.-Q.; Jin, Q.; Li, W. Antibacterial Total Phenolic Compounds from a Brown Alga Hizikia fusiformis. DEStech Trans. Environ. Energy Earth Sci. 2017, 418-425. [CrossRef]

99. Tang, J.; Wang, W.; Chu, W. Antimicrobial and Anti-Quorum Sensing Activities of Phlorotannins From Seaweed (Hizikia fusiforme). Front. Cell. Infect. Microbiol. 2020, 10, 586750. [CrossRef]

100. Cartea, M.E.; Francisco, M.; Soengas, P.; Velasco, P. Phenolic compounds in Brassica vegetables. Molecules 2011, 16, 251-280. [CrossRef]

101. Arshad, M.A.; Khurshid, U.; Ahmad, S.; Ijaz, S.; Rashid, F.; Azam, R. Review on methods used to determine Antioxidant activity. Intern. Ional. J. Mul. Tidisc. Iplinary Res. Dev. 2014, 1, 41-46.

102. Dai, Y.; Jiang, Y.; Lu, Y.; Kang, M.; Jeon, Y. Fucoidan from acid-processed Hizikia fusiforme attenuates oxidative damage and regulate apoptosis. Int. J. Biol. Macromol. 2020, 160, 390-397. [CrossRef]

103. Wu, M.; Wu, Y.; Qu, M.; Li, W.; Yan, X. Evaluation of antioxidant activities of water-soluble polysaccharides from brown alga Hizikia fusiformis. Int. J. Biol. Macromol. 2013, 56, 28-33. [CrossRef]

104. Chen, P.; Zhang, Y.; Xu, M.; Chen, H.; Zou, H.; Zhang, X.; Tong, H.; You, C.; Wu, M. Proteomic landscape of liver tissue in old male mice that are long-term treated with Polysaccharides from Sargassum fusiforme. Food Funct. 2020, 11, 3632-3644. [CrossRef]

105. Oktaviani, D.F.; Bae, Y.; Dyah, M.; Meinita, N.; Moon, I.S. An Ethanol Extract of the Brown Seaweed Hizikia fusiformis and Its Active Constituent, Fucosterol, Extend the Lifespan of the Nematode Caenorhabditis elegans. J. Life Sci. 2019, 29, 1120-1125. [CrossRef] 
106. Park, C.; Lee, H.; Hwangbo, H.; Ji, S.Y.; Kim, M.Y.; Kim, S.Y.; Hong, S.H.; Kim, G.Y.; Choi, Y.H. Ethanol extract of Hizikia fusiforme induces apoptosis in B16F10 mouse melanoma cells through ROS-dependent inhibition of the PI3K/Akt signaling pathway. Asian Pac. J. Cancer Prev. 2020, 21, 1275-1282. [CrossRef]

107. Choi, E.O.; Lee, H.; Park, C.; Kim, G.Y.; Cha, H.J.; Kim, H.S.; Jeon, Y.J.; Hwang, H.J.; Choi, Y.H. Ethanol extracts of Hizikia fusiforme induce apoptosis in human prostate cancer PC3 cells via modulating a ROS-dependent pathway. Asian Pac. J. Trop. Biomed. 2020, 10, 78-86. [CrossRef]

108. Dai, Y.L.; Jiang, Y.F.; Nie, Y.H.; Lu, Y.A.; Kang, M.C.; Jeon, Y.J. Hepato-protective effect of fucoidan extracted from acid-processed Sargassum fusiformis in ethanol-treated Chang liver cells and in a zebrafish model. J. Appl. Phycol. 2020, 32, 4289-4298. [CrossRef]

109. Lee, S.G.; Karadeniz, F.; Oh, J.H.; Yu, G.H.; Kong, C.S. Inhibitory effect of Hizikia fusiformis solvent-partitioned fractions on invasion and MMP activity of HT1080 human fibrosarcoma cells. Prev. Nutr. Food Sci. 2017, 22, 184-190. [CrossRef]

110. Fuchs, Y.; Steller, H. Programmed cell death in animal development and disease. Cell 2011, 147, 742-758. [CrossRef] [PubMed]

111. Wong, R.S.Y. Apoptosis in cancer, From pathogenesis to treatment. J. Exp. Clin. Cancer Res. 2011, 30, 87. [CrossRef]

112. Pistritto, G.; Trisciuoglio, D.; Ceci, C.; Garufi, A.; D'Orazi, G. Apoptosis as anticancer mechanism: Function and dysfunction of its modulators and targeted therapeutic strategies. Aging 2016, 8, 603-619. [CrossRef]

113. Buckley, C.D.; Gilroy, D.W.; Serhan, C.N.; Stockinger, B.; Tak, P.P. The resolution of inflammation. Nat. Rev. Immunol. 2013, 13, 59-66. [CrossRef]

114. Sharma, B.R.; Park, C.S.; Ma, S.J.; Rhyu, D.Y. Anti-inflammatory effects and mechanisms of Hizikia fusiformis via multicellular signaling pathways in lipopolysaccharide-induced RAW 264.7 cells. Pak. J. Pharm. Sci. 2017, 30, 43-48.

115. Hwang, E.; Park, S.Y.; Shin, H.S.; Lee, D.G.; Yi, T.H. Effect of oral administration of fucosterol from Hizikia fusiformis on DNCB-induced atopic dermatitis in NC/Nga mice. Food Sci. Biotechnol. 2014, 23, 593-599. [CrossRef]

116. Lee, K.H.; Kim, H.J.; Kim, H.B.; Kim, S.T.; Choi, Y.R.; Seo, D.W.; Yu, J.M.; Kil Jang, S.; Kim, S.M.; Lee, D.-I.; et al. Hizikia fusiformis fractions successfully improve atopic dermatitis indices in anti-CD3-stimulated splenocytes and 2, 4-dinitrochlorobenzene-treated BALB/c mice. J. Pharm. Pharmacol. 2013, 66, 466-476. [CrossRef]

117. Zhang, Y.L.; Shin, H.J.; Lee, J.H.; Lee, J. Antiallergic effect of Hizikia fusiformis in an ovalbumin-induced allergic rhinitis mouse model. Clin. Exp. Otorhinolaryngol. 2019, 12, 196-205. [CrossRef] [PubMed]

118. Leung, D.Y.M.; Bieber, T. Atopic dermatitis. Lancet 2003, 361, 151-160. [CrossRef]

119. Solano, F. Photoprotection and skin pigmentation, Melanin-related molecules and some other new agents obtained from natural sources. Molecules 2020, 25, 1537. [CrossRef] [PubMed]

120. Wang, L.; Oh, J.Y.; Lee, W.W.; Jeon, Y.J. Fucoidan isolated from Hizikia fusiforme suppresses ultraviolet B-induced photodamage by down-regulating the expressions of matrix metalloproteinases and pro-inflammatory cytokines via inhibiting NF- $\mathrm{B}$, AP-1, and MAPK signaling pathways. Int. J. Biol. Macromol. 2021, 166, 751-759. [CrossRef]

121. Wang, L.; Oh, J.Y.; Jayawardena, T.U.; Jeon, Y.; Ryu, B. Anti-inflammatory and anti-melanogenesis activities of sulfated polysaccharides isolated from Hizikia fusiforme, Short communication. Int. J. Biol. Macromol. 2019, 142, 545-550. [CrossRef] [PubMed]

122. Wang, L.; Oh, J.Y.; Kim, Y.S.; Lee, H.G.; Lee, J.S.; Jeon, Y.J. Anti-photoaging and anti-melanogenesis effects of fucoidan isolated from Hizikia fusiforme and its underlying mechanisms. Mar. Drugs 2020, 18, 427. [CrossRef] [PubMed]

123. Lee, S.G.; Kang, H. Evaluation of antioxidant and anti-neuroinflammatory activities of Hizikia fusiformis (Harvey) okamura extract. Trop. J. Pharm. Res. 2015, 14, 463-468. [CrossRef]

124. Kang, C.H.; Kim, M.J.; Seo, M.J.; Choi, Y.H.; Jo, W.S.; Lee, K.T.; Jeong, Y.K.; Kim, G.Y. 5-Hydroxy-3,6,7,8,3040-hexamethoxyflavone inhibits nitric oxide production in lipopolysaccharide-stimulated BV2 microglia via NF- $\mathrm{kB}$ suppression and Nrf-2-dependent heme oxygenase-1 induction. Food Chem. Toxicol. 2013, 57, 119-125. [CrossRef]

125. Bogie, J.; Hoeks, C.; Schepers, M.; Tiane, A.; Cuypers, A.; Leijten, F.; Chintapakhorn, Y.; Suttiyut, T.; Pornpakakul, S.; Struik, D.; et al. Dietary Sargassum fusiforme improves memory and reduces amyloid plaque load in an Alzheimer's disease mouse model. Sci. Rep. 2019, 9, 1-17. [CrossRef]

126. DiSabato, D.; Quan, N.; Godbout, J.P. Neuroinflammation, The Devil Is in the Details. Ann. Surg. Oncol. 2021, $28,11-13$. [CrossRef] [PubMed]

127. Kang, S.; Kim, E.; Kang, I.; Lee, M.; Lee, Y. Anti-diabetic effects and anti-inflammatory effects of Laminaria japonica and Hizikia fusiforme in skeletal muscle, In vitro and in vivo model. Nutrients 2018, 10, 491. [CrossRef]

128. Jia, R.; Li, Z.R.; Wu, J.; Ou, Z.R.; Liao, B.; Sun, B.; Lin, L.; Zhao, M. Mitigation mechanisms of Hizikia fusifarme polysaccharide consumption on type 2 diabetes in rats. Int. J. Biol. Macromol. 2020, 164, 2659-2670. [CrossRef]

129. Polak, E.; Stępień, A.E.; Gol, O.; Tabarkiewicz, J. Potential immunomodulatory effects from consumption of nutrients in whole foods and supplements on the frequency and course of infection, Preliminary results. Nutrients 2021, 13, 1157. [CrossRef]

130. Avorn, J.M.D. Learning abot the Safety of Drugs. A Half-Century of Evolution. N. Engl. J. Med. 2011, 365, 2151-2153. [CrossRef] [PubMed]

131. Kim, M.E.; Cho, J.H.; Jung, I.; Kim, H.K.; Lee, J.S. Hizikia fusiforme extract enhances dendritic cell maturation in vitro and in vivo. Biosci. Biotechnol. Biochem. 2020, 84, 1861-1869. [CrossRef]

132. Yoon, Y.D.; Lee, E.S.; Park, J.P.; Kim, M.R.; Lee, J.W.; Kim, T.H.; Na, M.K.; Kim, J.H. Immunostimulatory effect by aqueous extract of Hizikia fusiforme in RAW 264.7 macrophage and whole spleen cells. Biotechnol. Bioprocess. Eng. 2011, 16, 1099-1105. [CrossRef]

133. Kuyinu, E.L.; Narayanan, G.; Nair, L.S.; Laurencin, C.T. Animal models of osteoarthritis, Classification, update, and measurement of outcomes. J. Orthop. Surg. Res. 2016, 11, 1-27. [CrossRef] [PubMed] 
134. Jeong, Y.T.; Baek, S.H.; Jeong, S.C.; Yoon, Y.D.; Kim, O.H.; Oh, B.C.; Jung, J.W.; Kim, J.H. Osteoprotective Effects of PolysaccharideEnriched Hizikia fusiforme Processing Byproduct In Vitro and In Vivo Models. J. Med. Food 2016, 19, 805-814. [CrossRef] [PubMed]

135. Hwang, H.; Kim, I.; Nam, T. Protective Effect of Polysaccharide from Hizikia fusiformis against Ethanol-Induced Toxicity. In Advances in Food and Nutrition Research; Academic Press: New York, NY, USA, 2011; Volume 64, pp. 143-161. [CrossRef] [PubMed]

136. Higham, J.; Kang, J.Y.; Majeed, A. Recent trends in admissions and mortality due to peptic ulcer in England, Increasing frequency of haemorrhage among older subjects. Gut 2002, 50, 460-464. [CrossRef] [PubMed] 